\section{Carbapenemase-producing bacteria in food-producing animals, wildlife and environment: $A$ challenge for human health}

\author{
Silvia Bonardi, Rosario Pitino \\ Department of Veterinary Science, \\ University of Parma, Italy
}

\begin{abstract}
Antimicrobial resistance is an increasing global health problem and one of the major concerns for economic impacts worldwide. Recently, resistance against carbapenems (doripenem, ertapenem, imipenem, meropenem), which are critically important antimicrobials for human cares, poses a great risk all over the world. Carbapenemases are $\beta$-lactamases belonging to different Ambler classes (A, B, D) and encoded by both chromosomal and plasmidic genes. They hydrolyze a broad variety of $\beta$-lactams, including carbapenems, cephalosporins, penicillins and aztreonam. Despite several studies in human patients and hospital settings have been performed in European countries, the role of livestock animals, wild animals and the terrestrial and aquatic environment in the maintenance and transmission of carbapenemase-producing bacteria has been poorly investigated. The present review focuses on the carbapenemase-producing bacteria detected in pigs, cattle, poultry, fish, mollusks, wild birds and wild mammals in Europe as well as in non-European countries, investigating the genetic mechanisms for their transmission among food-producing animals and wildlife. To shed light on the important role of the environment in the maintenance and genetic exchange of resistance determinants between environmental and pathogenic bacteria, studies on aquatic sources (rivers, lakes, as well as wastewater treatment plants) are described.
\end{abstract}

\section{Introduction}

The resistance against carbapenems is of great public concern, because they are among the most critically important antimicrobials for human treatments (WHO, 2017). In fact, these antimicrobials have the broadest spectrum of activity in vitro against Gram-positive and Gram-negative bacteria, including anaerobes (Zhanel et al., 2007). Hence, they are often used as "last- line agents" or "antibiotics of last resort" to treat infections caused by multidrug-resistant Gram-negative bacteria (GNB) (Zhanel et al., 2007; Nordmann et al., 2011; Patel and Bonomo, 2013). In order to preserve their efficacy, the use in animal species should be banned (WHO, 2015). Carbapenems (biapenem, doripenem, ertapenem, faropenem, imipenem, meropenem, panipenem) are potent members of the $\beta$-lactam family and occupy a unique position among $\beta$-lactams because they are resistant to most $\beta$-lactamases from Gram-positive and Gram-negative bacteria. In fact, even if carbapenems share a penicillin-like ring with penicillins and cephalosporins, they possess a carbon instead of a sulfone in the fourth position of the thyazolidinic mojety of the $\beta$-lactam ring (Kattan et al., 2008). Carbapenems are very efficient to treat a wide variety of infections such as complicated intraabdominal infections, skin and skin structure infections, community-acquired and nosocomial pneumonia, complicated urinary tract infections, meningitis (meropenem only) and febrile pneumonia (Janssen et al., 2015). Furthermore, the use of carbapenems is rising in humans in response to the increase of Extended-Spectrum BetaLactamase (ESBL)-producers and other multiresistant bacteria (Ashiru-Oredope et $a l ., 2012$ ). All clinically available carbapenems have low oral bioavailability because they do not cross the gastrointestinal barrier readily and must be administered intravenously; however, the combination imipenem-cilastatin and ertapenem can also be delivered intramuscularly (Papp-Wallace et al., 2011). Since the use of carbapenems has never been licensed for food-producing animals in any country worldwide (WHO, 2015), their residues in foods of animal origin are not actually allowed. Among microorganisms involved in the antimicrobial resistance (AMR) phenomenon, GNB are becoming increasingly resistant to most antibiotics (Blair et al., 2014). Specifically, this trend is highlighted in Enterobacteriaceae, whose members are often involved into a wide variety of community and health-care infections (Grundmann et al., 2010; Nordmann et al., 2011; Albiger et al., 2015; Grundmann et al., 2017; Magiorakos et al., 2017). However, during the last years, several studies have shown the worldwide increase, in terms of prevalence, of carbapenem resistance in non-fermenting microorganisms, such as Pseudomonas spp. and Acinetobacter spp. (Miriagou et al., 2010; Pfeifer et al., 2010; Papp-Wallace et al., 2011; EFSA, 2013).

The main mechanism of resistance to $\beta$ -
Correspondence: Silvia Bonardi, Department of Veterinary Science, University of Parma, Strada del Taglio 10, 43126, Parma, Italy.

Tel.: +39.0521.032744

E-mail: silvia.bonardi@unipr.it

Key words: Carbapenemase-producing bacteria, Livestock, Fish, Wildlife, Environment

Contributions: the authors contributed equally.

Conflict of interests: the authors declare no potential conflict of interests.

Funding: this review received no funding

Received for publication: 29 November 2018 Revision received: 9 May 2019.

Accepted for publication: 9 May 2019.

This work is licensed under a Creative Commons Attribution-NonCommercial 4.0 International License (CC BY-NC 4.0).

(C) Copyright S. Bonardi and R. Pitino, 2019 Licensee PAGEPress, Italy

Italian Journal of Food Safety 2019; 8:7956

doi:10.4081/ijfs.2019.7956

lactams among GNB is due to the presence of $\beta$-lactamases. Among over 1,000 of naturally occurring $\beta$-lactamases, carbapenemases with either serine-based or zinc-facilitated hydrolysis mechanisms are posing some of the most critical problems (Bush and Fisher, 2011). Among GNB, Carbapenem-Producing Enterobacteriaceae (CPE) are arising as an important challenge in health-care settings all over the world (Bush and Fisher, 2011; Nordmann et al., 2011) especially because they can acquire resistance by horizontal transfer of genes carried by mobile genetic elements (Woodford et al., 2014).

As well-known, the use of antimicrobials leads to a selective pressure for resistant strains both in humans and animals (Woodford et al., 2014). For instance, the detection of carbapenem-resistant bacteria in food-producing animals may be due to the use of extended-spectrum cephalosporins on farm. The exact relationship between extended-spectrum cephalosporin use and carbapenem-resistance has not fully been established (Mollenkopf et al., 2017), even if plasmids carrying genes conferring both resistance to carbapenems (bla $\left.a_{\mathrm{VIM}-1}\right)$ and third-generation cephalosporins $\left(b l a_{\mathrm{ACC}-1}\right)$ have been recently found in bacteria isolated from livestock (Falgenhauer et al., 2017). This finding needs further studies, since administration of these drugs is commonly reported when carbapenemresistance microorganisms are found in 
food-producing animals. This short review is focused on the occurrence of carbapenemase-producing $(\mathrm{CP})$ bacteria in food-producing animals, natural environment and wildlife and its major goal is to trace their spreading and evolution out of the human compartment. Only studies which demonstrated the occurrence of $\mathrm{CP}$ bacteria out of the human compartment are described. Even if data from food-producing animals and environmental sources are fragmentary and often their epidemiological links seem to be not clear, our efforts aimed to select the studies which clearly described $i$ ) the analytical methods used; ii) the genetic determinants for carbapenem-resistance; iii) the possible links between use of antimicrobials in livestock and selection of CP bacteria. When available, data on co-resistance to other antimicrobials and their genetic mechanisms of transmission are reported.

\section{Materials and Methods}

A systematic review of 308 studies published in the PubMed database between 1980 and 2018 was performed, with special interest for those reporting the detection of CP bacteria in food-producing animals, wildlife and the environment. We included three types of articles: $i$ ) the articles describing carbapenem-resistant bacteria isolated from livestock (pigs, cattle, poultry) and products thereof, included fish and molluscs, the natural environment and wild animals; $i$ ) the articles describing the different classes and variants of carbapenemases shared by bacteria of human and animal origin; iii) the articles describing the genomic traits of CP microorganisms isolated from livestock, wild animals and the environment. Studies primarily focused on laboratory methods for detection of $\mathrm{CP}$ bacteria were excluded, as well as those regarding carbapenem-resistant bacteria from companion animals (dogs and horses) or insects (flies).

Among the articles found by the entry criteria, only those showing data on CP bacteria and bacterial carriage of carbapenemase genes were included in the review, thus excluding all studies focused on bacterial resistance to carbapenems not based on carbapenemases production.

\section{Development of carbapenem- resistance}

Bacteria show resistance to carbapenems through several mechanisms: production of $\beta$-lactamases (carbapenemases), efflux pumps and mutations that alter the expression and/or function of porins and penicillin-binding proteins (PBPs). CP microorganisms are usually only susceptible to polymyxins (e.g. colistin), fosfomycin and variably susceptible to tigecycline, although colistin resistance in $\mathrm{CP}$ Klebsiella pneumoniae isolates has been recently reported (Nordmann et al., 2009; Pena et al., 2014; Otter et al., 2017).

Still other mechanisms can be active, the production of specific $\beta$-lactamases, called carbapenemases, is the most important to confer resistance against carbapenems. In fact, carbapenemases are able to hydrolyze carbapenems efficiently, while most other $\beta$-lactamases hydrolyze them very slowly (Temkin et al., 2014). Furthermore, carbapenemases hydrolyze a broad variety of $\beta$-lactams, including cephalosporins, penicillins and aztreonam and are inhibited by the $\beta$-lactamase inhibitors, such as clavulanic acid, tazobactam and sulbactam (Drawz and Bonomo, 2010).

Carbapenemases have been classified in three classes: the Ambler class A, B and D $\beta$ lactamases (Ambler, 1980). Ambler class C $\beta$-lactamases, on the contrary, possess a slightly extended activity towards carbapenems, but primarily hydrolyze cephalosporines (AmpC) (Jaurin and Grundstrom, 1981). Based on their hydrolytic activity, carbapenemases are divided into two groups: $i$ ) serine carbapenemases, which utilize the amino acid serine for $\beta$-lactam hydrolysis by forming an acyl enzyme (Class A and D); ii) metallo carbapenemases, which require at least one active-site zinc ions to facilitate $\beta$-lactam hydrolysis (Class B) (Hall and Barlow, 2005).

Class A carbapenemases can be chromosomally encoded, such as NmcA (Nonmetallo carbapenemase A), SME (Serratia marcescens enzyme), IMI-1 (Imipenemhydrolyzing $\beta$-lactamase), SFC-1 (Serratia fonticola carbapenemase), BIC-1 (Bicêtre carbapenemase), PenA (penicillinase from P. cepacia), FPH-1 (from Francisella philomiragia) and several members of SHV family, or plasmid encoded, such as KPCs (Klebsiella pneumoniae carbapenemases), GES (Guiana extended spectrum $\beta$-lactamase), IMI-2, and FRI-1 (Aubron et al., 2005; Naas et al., 2016). Chromosomally mediated AMR is vertically transmitted to daughter cells, and these microorganisms can be clinically relevant if they produce severe infections requiring antimicrobial therapy. However, bacterial $\beta$-lactamase genes located on mobile plasmids pose a far greater health threat because they may be transmitted horizontally among commensal bacterial and pathogens, thus potentially disseminating $\beta$-lactam resistance to a great variety of bacterial species. For example, in 2001, evidence of horizontal gene transfer (CMY-2 AmpC $\beta$-lactamase) was demonstrated in food-producing animal and human isolates of E. coli and Salmonella resistant to cephamycins and third-generation cephalosporins (Winokur et al., 2001). Since then, other studies have observed the transfer of plasmid-mediated carbapenem resistance between different bacterial species (Goren et al., 2010; Rumbo et al., 2011; Hardiman et al., 2016). In addition, evidence for the transfer of CP gene-containing transposons between plasmids has been demonstrated, as the $b l a_{\mathrm{KPC}-2}$ gene in $K$. pneumoniae. The $b l a_{\mathrm{KPC}-2}$ gene is located on the Tn- 3 related transposon Tn4401 capable of high frequency of transposition (Nordmann et al., 2009; Cuzon et al., 2011). The transposon Tn4401 has been also described in the plasmid pCOL-1 of $P$. aeruginosa, thus suggesting that it could be transferred among different microorganisms (Diene and Rolain, 2014).

KPCs are class A serine $\beta$-lactamases that spread primarily via the clonal dissemination of K. pneumoniae and some KPCproducing clones are dominant, such as the sequence type (ST) 258 (Cuzon et al., 2010), ST512 (Warburg et al., 2012) and ST11 (Cuzon et al., 2010; Baraniak et al., 2011). Beside the gene $b l a_{\mathrm{KPC}-2}$ (Nordmann et al., 2009; Cuzon et al., 2011), other $b l a_{\mathrm{KPC}}$ genes are present on a wide variety of plasmids, different for size, structure and nature (Gootz et al., 2009; Cuzon et al., 2010; Leavitt et al., 2010). KPCs comprise 22 variants that differ by one to five amino acid substitutions (Woodford et al., 2014). As KPC-1 sequence was found to be identical to $\mathrm{KPC}-2, \mathrm{KPC}-1$ is no longer a valid designation (Yigit et al., 2008).

Among class B metallo- $\beta$-lactamases (MBLs), the New Delhi metallo- $\beta$-lactamases (NDMs) and the Verona integronencoded metallo- $\beta$-lactamases (VIMs) are the most common. NDM-producing species comprise E. coli (Mushtaq et al., 2011; Cuzon et al., 2013) and K. pneumoniae (Pitout et al., 2015) but also Acinetobacter spp. (Zhang et al., 2014) and Pseudomonas spp. (Walsh et al., 2011). Dissemination of bla $_{\mathrm{NDM}-1}$ occurs both by horizontal and vertical transfer, since the coding sequence may be found on different plasmids or located on the chromosome (Poirel et al., 2011). To date, different variants of the NDM $\beta$-lactamases (NDM-1 to 7) have been identified in the Indian subcontinent (Rahman et al., 2014). VIM is an important MBL spread both in Enterobacteriaceae and non-fermenting bacteria. After the initial discovery of $b l a_{\mathrm{VIM}-1}$ in a clinical isolate of $P$. aerugi- 
nosa in Italy during 1997 (Lauretti et al., 1999), several variants have been reported in different species worldwide (Nordmann et al., 2011). The $b l a_{\mathrm{VIM}-1}$ group is detected mainly in Enterobacteriaceae, while the $b l a_{\mathrm{VIM}-2}$ group is found mainly in Acinetobacter and Pseudomonas species (Lee et al., 2003; Carattoli, 2009; Pena et al., 2014; Govender et al., 2015). Since the bla $_{\mathrm{VIM}}$ genes are often located within class 1 integrons that reside on broad-host range plasmids, they can be easily transferred between bacteria and contribute to the interspecies distribution of VIM-producing genes (Temkin et al., 2014; Mathers et al., 2015). Another important metallo- $\beta$-lactamase is IMP, which it is hardly blocked by $\beta$-lactamase inhibitors such as clavulanate, sulbactam and tazobactam (Ohsuka et al., 1995). As a consequence, strains producing IMP carbapenemase are difficult to control with $\beta$-lactams in combination with $\beta$-lactamase inhibitors (Senda et al., 1996), as amoxicillin-clavulanic acid combination. A total of 55 variants of the $b l a_{\mathrm{IMP}}$ gene have been described (Shakibaie et al., 2017) carried by both Enterobacteriaceae and nonfermenting Acinetobacter and Pseudomonas species (Osano et al., 1994; Chu et al., 2001; Sidjabat et al., 2015). The $b l a_{\mathrm{IMP}}$ genes are located in class 1 integrons carried by plasmids and can spread horizontally among different species (Sidjabat et al., 2015).

To class D carbapenemases belongs the OXA type family which is composed by more than 400 enzymes classified in 12 subgroups, namely the OXA-23, OXA24/40, OXA-48, OXA-51, OXA-58, OXA134a, OXA-143, OXA-211, OXA-213, OXA-214, OXA-229, and OXA-235 (Evans and Amyes, 2014). The OXA-48 enzyme is a serine class D type- $\beta$-lactamase with high activity against penicillins but weak activity against expanded-spectrum cephalosporins and carbapenems (Walther-Rasmussen and Hoiby, 2006). It represents the most commonly detected carbapenemase around the world (Nordmann et al., 2011) and OXA-48 producing strains commonly carry ESBL genes which confer also resistance to expanded-spectrum cephalosporins (Temkin et al., 2014). The bla $a_{\mathrm{OXA}-48}$ gene can be transferred by plasmids, transposon ( $\operatorname{Tn} 1999)$ or clonally (Carrër et al., 2010; Temkin et al., 2014), whereas its variant $b l a_{\text {OXA-181 }}$ is located on transposon Tn2013 (Potron et al., 2011). Other OXA-type enzymes may be found in Acinetobacter baumannii (Higgins et al., 2013) and other non-fermentative rods, as Pseudomonas aeruginosa (Pfeifer et al., 2010).

\section{Epidemiology of carbapenem- resistance among bacteria}

Across the globe, first reports of carbapenemases occurred in the 1980s. For over 20 years there were no significant reports with an exception represented by a limited spread of IMP metallo- $\beta$-lactamase in Aeromonas hydrophila in Japan (Senda et al., 1996; Temkin et al., 2014;). Afterwards, other cases were reported in London (1982) by Seoul imipenemase (SME-1) from Serratia marcescens (Yang et al., 1990), in California (1984) by imipenemase (IMI-1) from Enterobacter cloacae (Rasmussen et al., 1996) and in France (1990) by NMC-A from Enterobacter cloacae (Nordmann et al., 1993).

The most frequently carbapenemases associated with Enterobacteriaceae worldwide are those belonging to the KPC family (Woodford et al., 2011; Rimoldi et al., 2017; van Duin and Doi, 2017; Kim et al., 2018; Muggeo et al., 2018). In 2017, among the European Union (EU) and European Economic Area (EEA) countries, the highest detection rates for KPC-producing Klebsiella pneumoniae human invasive isolates were reported from Greece $(64.7 \%)$, Italy $(29.7 \%)$ and Romania $(22.5 \%)$, where the resistance situation for carbapenems remains problematic. On the contrary, very low to low prevalence $(0.1-1.7 \%)$ were generally notified from northern and western European countries. Overall, the EU/EEA population weighted mean percentage for K. pneumoniae was $7.2 \%$ in 2017 (ECDC, 2018). Since resistance to carbapenems in $K$. pneumoniae is mediated by a wide range of carbapenemases, such as KPC, NDM, OXA-48-like and VIM, although with wide variation in prevalence (Grundmann et al., 2017), CP K. pneumoniae strains may show resistance to all available $\beta$-lactams. Additionally, high percentage of isolates have co-resistance to fluoroquinolones, third-generation cephalosporins and aminoglycosides (ECDC, 2018).

Carbapenem-resistance among human invasive Escherichia coli strains was still reported to be rare in all EU/EEA countries, with a population weighted mean percentage of $0.1 \%$ in 2017 (ECDC, 2018). Carbapenem-resistance combined with resistance to other important antimicrobial groups was commonly reported in P. aeruginosa in many EU/EEA countries in 2017, with a weighted mean of $17.4 \%$ (ECDC, 2018). Unlike other bacteria, carbapenemresistance in $P$. aeruginosa is multifactorial, due to plasmid or integron-coded carbapenemases, increased expression of efflux sys- tems, reduced porin expression and increased chromosomal cephalosporinase activity (Meletis et al., 2012). Regarding Acinetobacter baumanni, the epidemiological situation for carbapenem-resistance strains has been worsening in several European countries. Like $K$. pneumoniae and $E$. coli, carbapenem-resistance in $A$. baumannii is often mediated by carbapenemases production. In 2017, several European countries reported high percentages of resistance against carbapenems in Acinetobacter spp., which ranged from $0.0 \%$ in some northern countries (Denmark, Norway and Sweden) to $96.2 \%$ (Croatia). southern and eastern countries, like Italy, Latvia, Bulgaria, Romania, Lithuania and Greece reported prevalence values of $78.7 \%, 79.4 \%, 80.4 \%, 87.4 \%, 88.5 \%$ and $94.8 \%$, respectively (ECDC, 2018).

The so called 'big five' carbapenemase families collectively cause the greatest clinical concern. They include the KPC and OXA-48-like non-metallo-enzymes and the IMP, NDM and VIM metallo-enzymes (Nordmann et al., 2011; Patel and Bonomo 2013). There are significant country and regional differences in the importance of these families. In Europe, the KPC, OXA48-like, NDM and VIM enzymes commonly dominate (Cantón et al., 2012), whereas IMP enzymes are more prevalent in the Far East and Australia (Chen et al., 2014). Furthermore, the genes responsible for resistance to carbapenems are frequently associated with genes coding for resistance to non- $\beta$-lactam antimicrobials, giving rise to the so called multidrug resistant (MDR) microorganisms (Nordmann et al., 2011).

\section{Food-producing animals and car- bapenemase-producing bacteria}

The occurrence of CP bacteria in foodproducing animals has been reported from several countries. Pigs and chickens represent the most investigated species, in which carbapenem-resistance in Enterobacteriaceae and non-fermenting microorganisms (Acinetobacter spp. and Pseudomonas spp.) has been most frequently observed. Different classes of carbapenemases have been found both in Enterobacteriaceae and non-fermenting bacteria carried by livestock animals (Patel and Bonomo 2013).

\section{Pigs}

The most important studies on the detection of CP bacteria in pigs are shown in Tables 1 and 2 .

The first detection of $\mathrm{CP}$ microorganisms in this animal species dates back to 
2011, when a VIM-1- producing E. coli strain was isolated from a pig farm holding 4,100 pigs in Germany (Fischer et al., 2012). It was resistant to penicillin, cephalosporins, cephamycin, and amoxicillin/clavulanic acid, but was susceptible to aztreonam and intermediate/susceptible to carbapenems (imipenem, ertapenem and meropenem). By PCR, the isolate was found to harbor both the Amp-encoding gene $b l a_{\mathrm{ACC}-1}$ and the carbapenemaseencoding gene $b l a_{\mathrm{VIM}-1}$ located in a class 1 integron labelled In110. This integron had been previously identified in other enterobacteria, such as Klebsiella oxytoca and Enterobacter cloacae, as well as in Pseudomonas aeruginosa and Pseudomonas putida in Italy and Spain
(Riccio et al., 2005; Tato et al., 2010). The German VIM-1-producing E. coli strain represented the first CP microorganism isolated from pigs in Europe, but its sequence type (ST88) had been previously identified also among chickens, cattle and humans in Germany (Fischer et al., 2012). Retrospectively, it was observed that the VIM-1-positive E. coli ST88 strain was

Table 1. Carbapenemase-producing Enterobacteriaceae from livestock.

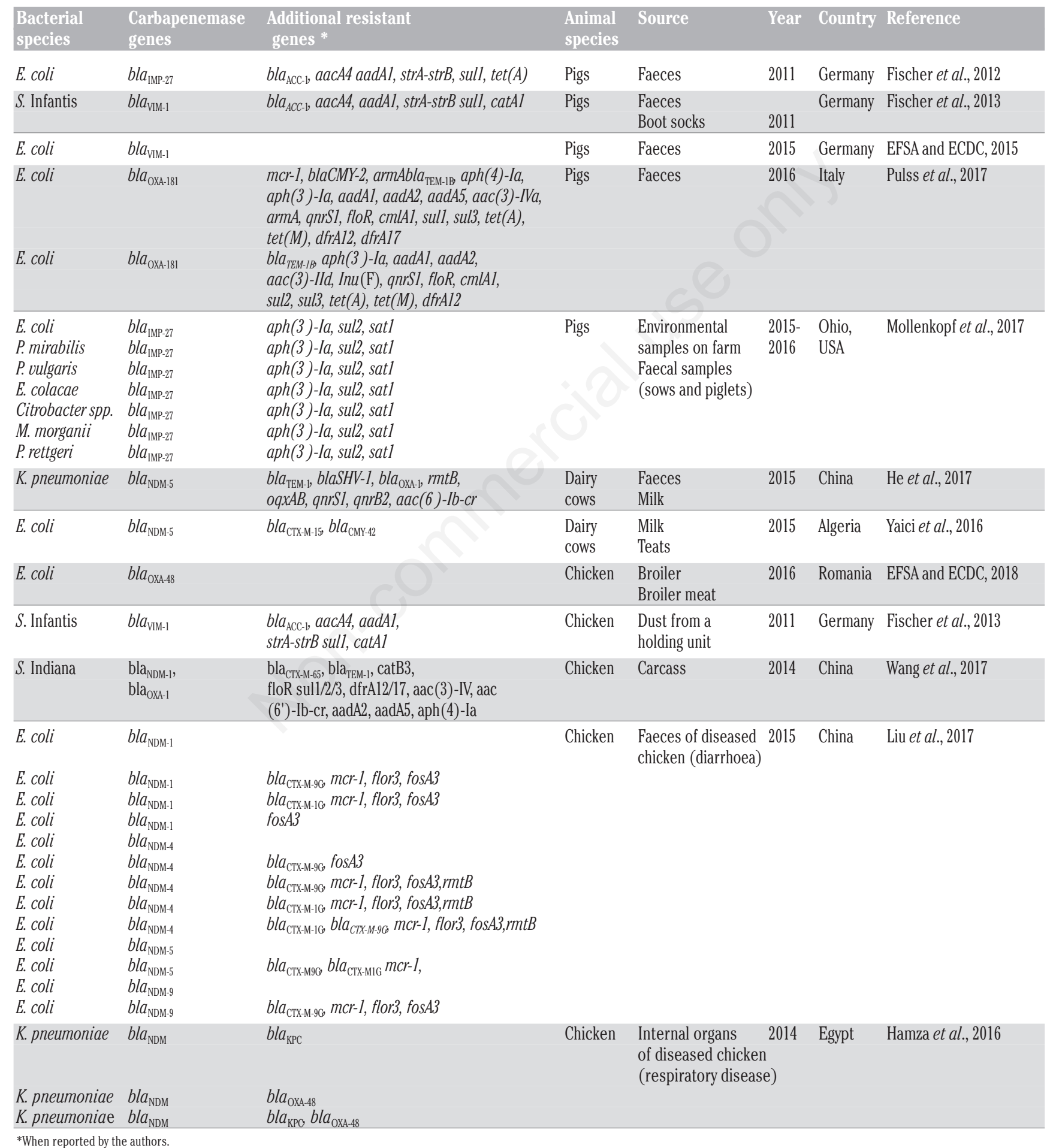


widely distributed in the fattening-pig farm tested in 2011, demonstrating that persistence and dissemination of CP microorganisms on farm was possible (Fischer et al., 2017). In 2011-2012, another German study revealed the occurrence of VIM-1-producing Salmonella Infantis from two pig farms and one broiler farm (Fischer et al., 2013a). The isolates carried both the gene $b l a_{\mathrm{ACC}-1}$ and the gene $b l a_{\mathrm{VIM}-1}$; the $b l a_{\mathrm{VIM}-1}$ gene was located on a class 1 integron harbored by a $\sim 300 \mathrm{~kb}$ IncH12 plasmid, which also carried the $b l a_{\mathrm{ACC}-1}$ gene. The sequence type (ST32) and PFGE pattern of the isolates were shared with other $S$. Infantis strains of human, poultry and pig origin previously detected in Germany (Fischer et al., 2017). Noteworthy, $S$. Infantis is among the top five Salmonella serovars responsible for human salmonellosis in Europe, ranking in fourth place in 2017, after Enteritidis, Typhimurium and monophasic Typhimurium (EFSA and ECDC, 2018a) and responsible for severe cases of human salmonellosis, characterized by septicemia and even death (Naas et al., 2011). As a consequence, the detection of carbapenemase-producing $S$. Infantis in pigs and poultry, which are considered its main reservoir, is of great concern (Hauser et al., 2012; EFSA, 2013; Hindermann et al., 2017).

Further studies revealed that in VIM-1producing $S$. Infantis and VIM-1-producing $E$. coli, isolated on the same farms, the bla $_{\mathrm{VIM}-1}$ gene was located on the IncH12 plasmid, also found in human strains. The IncH12 plasmid in $S$. Infantis (pRH-R27) was a mosaic plasmid with high homology to the plasmids isolated from the human strains, while the IncH12 plasmid in $E$. coli (pRH-R178) was a deletion derivative of the pRH-R27 found in $S$. Infantis, suggesting that selective evolution of plasmids in the livestock environment is possible (Falgenhauer et al., 2017). Since carbapenems are not used in animal husbandry in Germany, the source of the $b l a_{\mathrm{VIM}-1}$ gene could be identified in the selective pressure caused by third-generation cephalosporins. In fact, pRH-R27 and pRH-R178 plasmids harbored a plasmid-encoded AmpC $\beta$-lactamase $\left(b l a_{\mathrm{ACC}-1}\right)$ which confers resistance to third-generation cephalosporins (Falgenhauer et al., 2017).

As recently observed, the presence of genes encoding resistance to antimicrobials frequently used in swine production (e.g sulfonamides, cephalosporins) might be favored by minimal selective concentrations of the agents (below almost up to 140fold the MIC value). Therefore, even a very low drug concentration found in livestock environments and in treated humans and animals might be sufficiently high to select and maintain plasmids carrying resistance in the bacterial populations (Gullberg et al., 2014).

In 2015, mandatory monitoring for ESBL-/AmpC-/carbapenemase-producing E. coli was performed on caecal contents from 6,167 fattening pigs, 2,347 calves under one year of age and 10,679 meat samples thereof in 23 member states and two non-member states in Europe. As recommended by EUCAST (2015) a screening breakpoint for cefotaxime and/or ceftazidime ( $>1 \mathrm{mg} / \mathrm{L}$ ) was applied to screen for ESBL and AmpC-producers. Lower ECOFF breakpoints were applied for meropenem $(>0.125 \mathrm{mg} / \mathrm{L})$, imipenem (> $0.5 \mathrm{mg} / \mathrm{L})$ and ertapenem $(>0.06 \mathrm{mg} / \mathrm{L})$ to screen for CP E. coli. Regarding ESBL and AmpC producers, prevalence was high for the former $(31.9 \%$ and $36.8 \%$ in pigs and calves, respectively) and low for the latter (9.75 and $4.8 \%$ in pigs and calves, respectively) (EFSA and ECDC, 2017b). One VIM-1 E. coli strain was reported from pigs by Germany, thus confirming persistence of VIM-1-producing E. coli in the German pig population for at least four years (Irrgang et al., 2016). In addition, a CP E. coli strain was isolated from pig meat in Belgium (EFSA and ECDC, 2017b).

Recently, the occurrence of $b l a_{\text {OXA-181 }} E$. coli from two pigs reared in an Italian farm was reported. The two strains were not genetically related, belonging to sequence types ST359 and ST641. One of the isolates carried also the colistin-resistance gene $m c r-1$ and the aminoglycoside-resistance gene $\operatorname{arm} A$. The gene $b l a_{\text {OXA-181 }}$ was located on a $51.5-\mathrm{kb}$ non-conjugative IncX3 plasmid and the $m c r-1$ gene on a $33.3-\mathrm{kb}$ transferable IncX4 plasmid; both plasmids showed high similarity to human and animal ones, demonstrating that antimicrobial resistance plasmids are largely distributed in E. coli strains (Pulss et al., 2017).

The occurrence of plasmid-borne carbapenemase genes among Enterobacteriaceae in pigs was also reported in the USA. From environmental and faecal samples collected from swine farrowing and nursery barns, $18(5.6 \%) b^{\prime} a_{\mathrm{IMP}}$ ${ }_{27}$-harboring isolates belonging to the Enterobacteriaceae family (E. coli, Proteus spp., Morganella spp., Providencia spp., Citrobacter spp., Klebsiella spp.) were identified (Mollenkopf et al., 2017). The $b l a_{\mathrm{IMP}-27}$ is considered rare among the $\beta$-lactamase genes in the Unites States (Widmann et al., 2012). Positive selection pressure due to cephalosporins use at farm was related to the higher prevalence of $b l a_{\mathrm{IMP}-27}$ carrying isolates in the farrowing barn, compared to the nursery and finishing barns. In fact, ceftiofur was given to all piglets after birth (days 0 to 1 ) and to males at castration (day 5 to 7). In all the isolates, the $b l a_{\mathrm{IMP}-27}$ gene was located on IncQ1 plasmids of $\sim 10 \mathrm{~kb}$, whose presence in multiple bacterial species strongly suggested that they were mobilizable (Mollenkopf et al., 2017). IncQ are small (5.1 to $14.0 \mathrm{~kb})$ plasmids able to replicate independently of their host, allowing to reach high copy numbers (Meyer, 2009). Even if IncQ plasmids are not self-transmissible, they can be mobilized by a type IV transporters provided by larger, self-transmissible, co-resident helper plasmids from incompatibility groups, including IncP, IncF, IncI, IncM, IncX, IncN, and IncW (Loftie-Eaton and

Table 2. Carbapenemase-producing non-Enterobacteriaceae from livestock.

\begin{tabular}{|c|c|c|c|c|c|c|c|}
\hline $\begin{array}{l}\text { Bacterial } \\
\text { species }\end{array}$ & $\begin{array}{l}\text { Carbapenemase } \\
\text { genes }\end{array}$ & $\begin{array}{l}\text { Additional resistant } \\
\text { genes * }\end{array}$ & $\begin{array}{l}\text { Animal } \\
\text { species }\end{array}$ & Source & Year & Country & Reference \\
\hline A. baumannii & $b l a_{\mathrm{NDM}-1}$ & $\begin{array}{l}\text { aphA6, ble, } \\
\operatorname{msr}(E)-\operatorname{mph}(E)\end{array}$ & Pigs & $\begin{array}{l}\text { Lungs of a } \\
\text { diseased pig } \\
\text { (pneumonia) }\end{array}$ & 2011-2012 & China & Zhang et al., 2013 \\
\hline $\begin{array}{l}\text { Acinetobacter } \\
\text { (related to A. lwoffii) }\end{array}$ & $b l a_{0 X A-23}$ & & Dairy cattle & Faeces & 2010 & France & Poirel et al, 2012 \\
\hline A. baumannii & $b l a_{\text {OXА-497 }}$ & & Dairy cattle & Faeces & 2014 & $\begin{array}{l}\text { New Mexico } \\
\text { and Texas, } \\
\text { USA }\end{array}$ & Webb et al., 2016 \\
\hline
\end{tabular}

$\begin{array}{lllllll}\text { A. lwoffii } \quad \text { bla } & \text { aphA6-1 } & \text { Chickens } & \text { Faeces } & 2010 & \text { China }\end{array}$

*When reported by the authors. 
Rawlings, 2012). An experimental study evaluated the use of amoxicillin and ertapenem in porcine models; each antimicrobial resulted in changes in the porcine gut microbiome causing elimination of key commensal bacteria and propagation of AMR genes, including $\beta$-lactamases. Specifically, amoxicillin promoted the selection of many AMR genes, efflux pumps and $\beta$-lactamases, while ertapenem triggered the emergence of genes encoding for $\beta$-lactamases and the $b l a_{\mathrm{IMP}-27}$ carbapenemase (Connelly et al., 2018). Besides this, other agents used in swine production, as heavy metals and disinfectants, could coselect for plasmids carrying resistance genes when there is no direct selective pressure (Johnson, 2017).

In South China a large survey on lungs, liver and lymph nodes of pigs, chickens and ducks was performed in 2011-2012. One $b_{\text {NDM-1 }} A$. baumannii isolate was detected in the lungs of a swine with pneumonia and sepsis, reared on a farm where different $\beta$ lactams, third- and fourth-generation cephalosporins (ceftriaxone and ceftiofur), aminoglycosides and quinolones were commonly administered to the pigs. This evidence suggests for selective pressure favoring the emergence of carbapenem-resistance among microorganisms. The $b l a_{\mathrm{NDM}-1}$ gene in A. baumannii was identified on a $47 \mathrm{~kb}$ transferable plasmid (Zhang et al., 2013). At last, a worrisome finding comes from India and concerns the detection of Shiga-toxin producing E. coli (STEC) carrying the $b l a_{\mathrm{NDM}}$ gene in piglets. In the farms of origin, history of usage of several antimicrobials, including third-generation cefalosporis, was reported. The STEC isolates were positive for stx 1 , stx2, eae and $h l y A$ genes and were also resistant to extended-spectrum beta-lactams and other antimicrobials (Pruthvishree et al., 2017), thus representing a very dangerous multidrug-resistant pathogen.

\section{Cattle}

The studies on CP bacteria in cattle are shown in Tables 1 and 2. The first report was about the genus Acinetobacter: Isolates closely related to $A$. lwoffii harboring the $b l a_{\text {OXA-23 }}$ gene were detected from dairy cattle in France in 2010. The transposon Tn2008 was identified as vehicle for the bla $a_{\text {OXA-23 }}$ gene spread among Acinetobacter spp. (Poirel et al., 2012). Interestingly, the $b_{l a \text { OXA-23 }}$ gene is widespread in A. baumannii, an opportunistic nosocomial pathogen which has become one of the most relevant multidrug-resistant microorganisms in hospitals all over the world, with transposon Tn2008 as its major vehicle (Antunes et al., 2014). In Germany, strains of A. indicus- like carrying a chromosomal $b l a_{\text {OXA-23 }}$ gene were isolated from nasal swabs of cattle. Although pathogenicity and zoonotic potential of the microorganism require further investigations, the emergence of CP bacteria from cattle harboring $b l a_{\text {OXA-23 }}$ with genetic relatedness to human clinical isolates is of concern (Klotz et al., 2017). In the USA, dairy cattle were found to shed $A$. baumannii harboring the novel bla $_{\mathrm{OXA}-497}$ gene, which is part of the OXA-51-like enzyme group, and Pseudomonas spp. with conserved domains of various carbapenemase-producing genes. In the farms of origin, third-generation cephalosporins (ceftiofur) were commonly used (Webb et al., 2016).

Klebsiella pneumoniae harboring $b l a_{\mathrm{NDM}-5}$ genes was isolated from milk and faecal samples of dairy cows with mastitis in China (Jiangsu Province) (He et al., 2017). This was the first report of $b l a_{\mathrm{NDM}-5}$ carrying $K$. pneumoniae from cattle, but bla NDM-5 E. coli and bla NDM-5 $_{\text {K }}$. pneumoniae had been previously isolated from human patients in several countries, including the UK (Hornsey et al., 2011), Singapore (Balm et al., 2013), Algeria (Sassi et al., 2014), Japan (Nakano et al., 2014), Denmark (Hammerum et al., 2015), The Netherlands (Bathoorn et al., 2015), Spain (Pitart et al., 2015), the USA (de Man et al., 2015), Australia (Wailan et al., 2015), South Korea (Cho et al., 2015), India (Krishnaraju et al., 2015) and China (Liu et al., 2016; Zhang et al., 2016). In the Chinese dairy farms, selective pressure due to $\beta$-lactams (amoxicillin, ceftiofur) used to treat cattle with mastitis could have favored the emergence of $b l a_{\mathrm{NDM}-5}$-harboring K. pneumoniae isolates. In all the isolates, the $b l a_{\mathrm{NDM}-5}$ gene was found on a $\sim 46 \mathrm{~kb}$ self-transmissible IncX3 pNDM-MGR194-like plasmid. Nevertheless, since the strains belonged to five different sequence types, clonal dissemination within the farms could be only partly responsible of their widespread. Interestingly, the genetic context of the IncX3 plasmid was nearly the same of a human $K$. pneumoniae plasmid designated pNDM-MGR194, previously reported in India, and also closed to $b l a_{\mathrm{NDM}-5}$-carrying plasmids harbored by human $E$. coli strains in China (He et al., 2017). Most of these isolates were recovered from human clinical specimens and one isolate of $b l a_{\mathrm{NDM}-5} E$. coli from a dog in Algeria (Yousfi et al., 2015). These evidences seem to support for transmission of IncX3 plasmids from human sources to animal ones. Recently, the $b l a_{\mathrm{NDM}}$ genes $\left(b l a_{\mathrm{NDM}-1}\right.$ and $\left.b l a_{\mathrm{NDM}-5}\right)$ have frequently been reported to be located on IncX3 plasmids among several species of Enterobacteriaceae (E. coli, K. pneumo- niae, Citrobacter freundii and E. cloacae) in China (Ho et al., 2012; Chen et al., 2016) implying that IncX3 plasmids may provide an efficient vehicle for dissemination of human $b l a_{\mathrm{NDM}}$ genes within bacterial strains of animal origin. Therefore, the role of the IncX3 plasmid in the spread of the $b l a_{\mathrm{NDM}-5}$ gene (maybe of human origin) in the Chinese dairy farms was suggested and opened options to re-transmission of bla $a_{\mathrm{NDM}-5}$-carrying plasmid/bacteria from animals to humans through the dairy food chain (He et al., 2017). This hypothesis seems to be confirmed by the occurrence of the IncX3 plasmid carrying the gene $b l a_{\mathrm{NDM}}$. ${ }_{5}$ in E. coli strains isolated from teats and milk of dairy cows in Algeria (Yaici et al., 2016).

\section{Poultry}

The most interesting studies on detection of CP bacteria in poultry are shown in Tables 1 and 2.

Regarding EU countries, presumptive CP commensal $E$. coli isolates from broilers and broiler meat were reported by 2 member states in 2016 (11 isolates from Cyprus and 3 isolates from Romania). In Romania, the $E$. coli isolates from broilers were identified to carry the $b l a_{\text {OXA-48 }}$ gene (EFSA and ECDC, 2018b).

Most studies on poultry have been performed in China and African countries. In China, one isolate of NDM-1-producing A. lwoffii resistant to eight of nine $\beta$-lactams, including imipenem, meropenem and ertapenem, was detected from 396 anal swab samples collected from chickens. The gene $b l a_{\mathrm{NDM}-1}$ was located on a $\sim 270-\mathrm{kb}$ self-transferable plasmid, designated pAL01. Although the use of carbapenems in food-producing animals is banned in China, other $\beta$-lactams such as penicillin and cephalosporins (cefradine, ceftiofur and cefotaxime) are commonly used, as observed in the above-mentioned chicken farm (Wang et al., 2012).

Also, from China, a $b l a_{\mathrm{NDM}-1}$ and $b l a_{\mathrm{OXA}}$ ${ }_{1}$-harboring Salmonella Indiana isolate from a chicken carcass at slaughter was reported. The strain carried other $\beta$-lactamases, amynoglicosides, phenicol and trimethoprim/sulphamethoxazole resistance genes for a total of more than 20 antimicrobial resistances (Wang et al., 2017). The occurrence of such extensively-drug resistance (XDR) phenotype in the genus Salmonella is of the greatest concern for human heath, due to its zoonotic attitude and widespread in the food chain.

High prevalence of $E$. coli carrying both resistance against colistin (gene $m c r-1$ ) and carbapenems (genes bla $a_{\mathrm{NDM}-1}$, bla $a_{\mathrm{NDM}-4}$, $b l a_{\mathrm{NDM}-5}$ and $\left.b l a_{\mathrm{NDM}-9}\right)$ was reported in broil- 
ers by another Chinese study. In the isolates, dissemination of $m c r-1$ and $b l a_{\mathrm{NDM}}$ genes was not clonal, but due to different plasmids (Liu et al., 2017).

In Egypt, a study on carbapenem-resistant $K$. pneumoniae in broiler chickens reared in different farms, drinking water on farms and humans working in contact with chickens was performed. CP K. pneumoni$a e$ was isolated from $15 \%$ of broilers and $6 \%$ of water samples. Among the poultry isolates $(n=15)$, all of them were $b l a_{\mathrm{NDM}^{-}}$ positive, including 11 isolates harboring $b l a_{\mathrm{KPC}}, b l a_{\mathrm{OXA} 48}$ and $b l a_{\mathrm{NDM}}$ and four harboring either $b l a_{\mathrm{KPC}}$ and $b l a_{\mathrm{NDM}}$ or $b l a_{\mathrm{OXA}-48}$ and $b l a_{\mathrm{NDM}}$. The isolates from drinking water $(n=3)$ were positive for $b l a_{\mathrm{KPC}}$ and $b l a_{\mathrm{NDM}}(n=1)$ or for all three genes $(n=2)$. In Egypt, a high proportion $(56 \%)$ of $K$. pneumoniae isolates from humans were positive for the three carbapenemase genes. This finding suggests that a high incidence of $\mathrm{CP} K$. pneumoniae in humans may contribute to its dissemination among food-producing animals and the livestock environment, thus increasing the risk of foodborne transmission to the consumers (Hamza et al., 2016).

\section{Fish and molluses}

To prevent bacterial infections in farmed fish, antimicrobials are often used in intensive aquaculture practises (Rogers and Basurco, 2009). This situation supports the occurrence of AMR bacteria in seafood products (Roschanski et al., 2017). Furthermore, fish and molluscs may acquire AMR bacteria from water sea polluted by sewage and agriculture drains. Although investigations on $\mathrm{CP}$ bacteria in fishery products are very rare, some important data can be achieved from literature. The studies focused on the detection of $\mathrm{CP}$ bacteria in seafood are shown in Table 3.

In 2013, A. baumannii isolates harboring the chromosomally encoded $b l a_{\text {OXA-51 }}$ gene and the acquired $b l a_{\mathrm{OXA}-23}$ gene were detected from two Pagellus acarne fished in the Mediterranean See. The microorganisms were resistant to aminoglycosides, third-generation cephalosporins and carbapenems (imipenem, meropenem, ertapenem). They belonged to the widespread clone A. baumannii ST2, which had reached fish living in the Mediterranean Sea (Brahmi et al., 2016). Another study focused on CP bacteria contamination of frozen seafood (included octopus, squid, clams, mussels and shrimps) imported from China and Korea identified $b l a_{\mathrm{OXA}-48}$-harboring Stenotrophomonas maltophilia, Pseudomonas putida and Myroides odoratimimus isolates (Morrison and Rubin, 2015).

Recently, a strain of VIM-1 producing E. coli ST10 has been isolated from Venus clams (Ruditapes philippinarum) harvested in the Italian Mediterranean Sea, suggesting that $\mathrm{CP}$ E. coli have reached the seafood chain of this country. Moreover, since Venus clams are often eaten raw, ideal conditions for transmission and spread to the consumers of CP bacteria and/or transfer of the respective plasmids could occur (Roschanski et al., 2017).

\section{Environment and carbapene- mase-producing bacteria}

The studies focused on the detection of $\mathrm{CP}$ bacteria from different environmental sources are shown in Table 4. Environmental contamination with antimicrobials, AMR bacteria and their transfer-

Table 3. Carbapenemase-producing Enterobacteriaceae and non-Enterobacteriaceae from fishery and wild animals.

\begin{tabular}{|c|c|c|c|c|c|c|c|}
\hline $\begin{array}{l}\text { Bacterial } \\
\text { species }\end{array}$ & $\begin{array}{l}\text { Carbapenemase } \\
\text { genes }\end{array}$ & $\begin{array}{l}\text { Additional resistant } \\
\text { genes * }\end{array}$ & $\begin{array}{l}\text { Animal } \\
\text { species }\end{array}$ & Source & Year & Country & Reference \\
\hline E. coli & $b l a_{\mathrm{VIM}-\mathrm{I}}$ & $\begin{array}{l}\text { bla }_{\mathrm{AcCl}}, \text { bla }_{\mathrm{SHV} 12} \text { aacA4-like, } \\
\left.\text { aadAl, aph( } 3^{\prime}\right)-X V, \\
\text { catB2, dfrAl4-like, mph(A), }\end{array}$ & $\begin{array}{l}\text { Venus clams } \\
\text { (Ruditapes } \\
\text { philippinarum) }\end{array}$ & N.S. & 2016 & $\begin{array}{l}\text { Mediterranean } \\
\text { Sea (Italy) }\end{array}$ & Roschanski et al., 2017 \\
\hline
\end{tabular}
catB2, dfra14-like, mph(A), philippinarum) qnrS1, strA-like, strB like, sull, sul2

\begin{tabular}{|c|c|c|c|c|c|c|c|}
\hline A. baumannii & $\begin{array}{l}b l_{\text {aXXA-23, }} \\
b l a_{0 \times A-51}\end{array}$ & $a a c\left(6^{\prime}\right)-I b, a a c\left(3^{\prime}\right)-I$ & $\begin{array}{l}\text { Fish } \\
\text { (Pagellus acarne) }\end{array}$ & $\begin{array}{l}\text { Gills } \\
\text { Gut }\end{array}$ & 2013 & $\begin{array}{l}\text { Mediterranean } \\
\text { Sea (Algeria) }\end{array}$ & Brahmi et al., 2016 \\
\hline $\begin{array}{l}\text { S. maltophilia } \\
\text { M. odoratimimus } \\
\text { P. putida } \\
\text { Stenotrophomonas spp. }\end{array}$ & $\begin{array}{l}\text { bla }_{\text {OXA-48 }} \\
\text { bla }_{\text {OXA-48 }} \\
\text { bla }_{\text {OXA-48 }} \\
\text { bla }\end{array}$ & 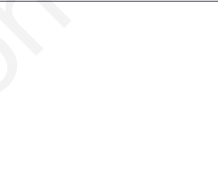 & $\begin{array}{l}\text { Seafood } \\
\text { medley } * * \\
\text { Clams } \\
\text { Squid } \\
\text { Sea squirt }\end{array}$ & $\begin{array}{l}\text { Edible } \\
\text { product }\end{array}$ & N.S. & $\begin{array}{l}\text { China } \\
\text { Korea }\end{array}$ & Morrison and Rubin, 2015 \\
\hline S. Corvallis & $b l a_{\mathrm{NDM}-1}$ & fosA3 & $\begin{array}{l}\text { Black kites } \\
\text { (Miluus migrans) }\end{array}$ & N.S. & N.S. & Germany & Fischer et al., 2013 \\
\hline E. coli & $b l a_{\mathrm{VIM}-1}$ & & $\begin{array}{l}\text { Yellow-legged gulls } \\
\text { (Larus michaellis) }\end{array}$ & Faeces & 2012 & France & Vittecoq et al., 2017 \\
\hline E. coli & $b l a_{\mathrm{IMP}-4}$ & qacG, aacA4, catB3 & $\begin{array}{l}\text { Silver gulls } \\
\text { (Chroicocephalus } \\
\text { novaehollandiae) }\end{array}$ & Faeces & 2012 & Australia & Dolejska et al., 2016 \\
\hline $\begin{array}{l}\text { E. coli } \\
\text { K. pneumoniae } \\
\text { K. pneumoniae } \\
\text { E. cloacae } \\
\text { C. freundii } \\
\text { P. mirabilis }\end{array}$ & $\begin{array}{l}\text { bla }_{\mathrm{IMP}-4} b l a_{\mathrm{IMP}-38} \\
\text { bla }_{\mathrm{IMP}-4} \\
\text { bla }_{\mathrm{IMP}-26} \\
\text { bla }_{\mathrm{IMP}-4} \\
\text { bla }_{\mathrm{IMP}-38} \\
\text { bla } \\
\text { blMP-4 }\end{array}$ & $\begin{array}{l}\text { qacG, aacA4, catB3 } \\
\text { qacG, aacA4, catB33 } \\
q a c G, \text { a acA4, catB3 } \\
\text { qacG, aacA4, catB3 } \\
\text { qacG, aacA4, catB3 }\end{array}$ & & & & & \\
\hline $\begin{array}{l}\text { E. coli } \\
\text { K. pneumoniae }\end{array}$ & $\begin{array}{l}b l a_{0 X-48} \\
b l a_{0 X A-48}\end{array}$ & & Wild boars & $\begin{array}{l}\text { Faeces } \\
\text { (Sus scro }\end{array}$ & $\begin{array}{l}2016 \\
f a)\end{array}$ & Algeria & Bachiri et al., 2017 \\
\hline
\end{tabular}

N.S., not specified. ${ }^{*}$ when reported by the authors. ${ }^{*}$ Seafood medley contains squid, octopus, mussels and shrimp. 
able resistance genes can pose a serious threat not only to human health, but to the natural environment microbial evolution as well (Martinez, 2009). Due to their use in livestock farming, antimicrobials may residue in manure applied to soil in agriculture practices. Besides this, AMR bacteria shed by animals may contaminate agricultural areas. In this way, both antimicrobials and AMR bacteria may be run-off from soil and reach surface water, then contributing to contamination of soil, crops and wild animals (Laxminarayan et al., 2013). To their turn, wild animals can enter in close contact with sewage and garbage, thus leading to a wide spread of AMR bacteria and resistance genes, with detrimental consequences for the entire ecosystem (Pesapane et al., 2013).

Bacteria carrying highly transferable resistant genes are of concern, because mobile elements could reach a wide variety of settings in which other bacterial species are present. For example, the use of water from polluted rivers in agriculture and aquaculture increases such risk of AMR bacteria spreading to more than one food chain (EFSA, 2013). One example is given by Salmonella in poultry, E. coli in livestock or $K$. pneumoniae in dairy cattle. Therefore, when AMR bacteria and their transferable resistant genes are lead to food- producing animals through polluted environment, the risk for potential contamination of their derived products should not be ignored (EFSA, 2013). The studies focused on the detection of CP bacteria from different environmental sources are shown in Table 4.

The detection of carbapenemase-encoding genes in bacteria from livestock environmental samples was reported in pig-fattening farms in Germany, where VIM-1positive Salmonella Infantis was isolated from boot socks taken outside of the farms and VIM-1-producing E. coli from manure and flies. Indeed, manure and insects can act as vectors of AMR bacteria at farm

Table 4. Carbapenemase-producing Enterobacteriaceae and non-Enterobacteriaceae from the environment.

\begin{tabular}{|c|c|c|c|c|c|c|}
\hline Bacterial species & $\begin{array}{l}\text { Carbapenemase } \\
\text { genes }\end{array}$ & $\begin{array}{l}\text { Additional resistant } \\
\text { genes * }\end{array}$ & Source & Year & Country & Reference \\
\hline $\begin{array}{l}\text { S. Infantis } \\
\text { E. coli }\end{array}$ & $\begin{array}{l}b l a_{\mathrm{VIM}-1} \\
b l a_{\mathrm{VIM}-1}\end{array}$ & $\begin{array}{l}b l a_{\mathrm{ACC}-1} \\
b a_{\mathrm{ACC}-1}\end{array}$ & $\begin{array}{l}\text { Boot socks outside pig farms } \\
\text { Manure and flies } \\
\text { (Pig farms) }\end{array}$ & 2011-2012 & Germany & Fischer et al., 2017 \\
\hline $\begin{array}{l}\text { Klebsiella spp., } \\
\text { Enterobacter spp., } \\
\text { Citrobacter spp., } \\
\text { Serratia spp., } \\
\text { Raoultella spp., } \\
\text { Aeromonas spp., } \\
\text { Kluyvera spp. }\end{array}$ & bla $_{\mathrm{KPC}-2}$ & & Hospital sewage WWTP ** & 2011 & Brazil & Picao et al., 2013 \\
\hline $\begin{array}{l}\text { E. coli } \\
\text { C. freundii } \\
\text { K. pneumoniae } \\
\text { K. pneumoniae }\end{array}$ & $\begin{array}{l}\text { bla }_{\text {OXA-48 }} \\
\text { bla }_{\mathrm{OXA}-48} \\
\text { bla }_{\mathrm{KPC}-2} \\
\text { bla }_{\mathrm{OXA}-48}\end{array}$ & & WWTP ** & 2015-2016 & Switzerland & Zurfluh et al., 2017 \\
\hline $\begin{array}{l}\text { K. pneumoniae } \\
\text { K. pneumoniae } \\
\text { E. coli }\end{array}$ & $\begin{array}{l}\text { bla }_{\mathrm{KPC}-2} \\
\text { bla }_{\text {OXA-48 }} \\
\text { bla }_{\text {OXA-48 }}\end{array}$ & 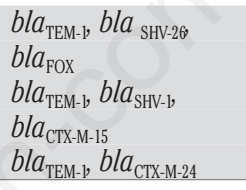 & WWTP ** & 2011-2012 & Austria & Galler et al., 2014 \\
\hline $\begin{array}{l}\text { P. aeruginosa } \\
\text { Brevundimonas diminuta } \\
\text { Rhizobium radiobacter } \\
\text { Pseudomonas monteilii } \\
\text { Ochrobactrum anthropic } \\
\text { Acinetobacter johnsonii }\end{array}$ & $\begin{array}{l}\text { bla }_{\mathrm{VIM}-13} \\
b a_{\mathrm{VIM}-13} \\
\text { bla }_{\mathrm{VIM}-13} \\
\text { bla }_{\mathrm{VIM}-13} \\
\text { bla }_{\mathrm{VIM}-13} \\
\text { bla }_{\text {OXA-58 }}\end{array}$ & $\begin{array}{l}\text { aacA4, sull } \\
\text { aacA4, sull } \\
\text { aacA4, sull } \\
\text { aacA4, sull }\end{array}$ & Hospital sewage water & N.S. & Spain & Scotta et al., 2011 \\
\hline P. aeruginosa & $b l a_{\text {VIM-2 }}$ & aаcA4, aacA7 aаcCl & Hospital sewage water; river & 2001-2005 & Portugal & $\begin{array}{l}\text { Quinteira and } \\
\text { Peixe, } 2006\end{array}$ \\
\hline K. pneumoniae & $\begin{array}{l}b l a_{\mathrm{IMP}-8} b l a_{\mathrm{IMP}-16} \\
b l a_{\mathrm{IMP}-13}\end{array}$ & $b l a_{\text {CTX-M-15, }} b l a_{\text {SHV-12a }}$ & Rivers & 2010 & Tunisia & $\begin{array}{l}\text { Chouchani et al., } \\
2013\end{array}$ \\
\hline $\begin{array}{l}\text { E. coli } \\
\text { K. pneumoniae } \\
\text { C. freundii } \\
\text { V. cholerae } \\
\text { Shigella boydii } \\
\text { Pseudomonas spp. } \\
\text { Stenotrophomonas } \\
\text { maltophilia } \\
\text { P. aeruginosa }\end{array}$ & $\begin{array}{l}b l a_{\mathrm{NDM}-1} \\
b l a_{\mathrm{NDM}-1} \\
\text { bla }_{\mathrm{NDM}-1}\end{array}$ & & Seepage water & 2010 & India & Walsh et al., 2011 \\
\hline A.baumannii & $b l a_{\text {OXA-23 }}$ & & Seine River & N.S. & France & Girlich et al. 2010a \\
\hline P. fluorescens & $b l a_{\mathrm{BIC}-1}$ & & Seine River & N.S. & France & Girlich et al., 2010b \\
\hline
\end{tabular}

N.S., not specified. ${ }^{*}$ when reported by the authors. ${ }^{* * W W T P: ~ w a s t e ~ w a t e r ~ t r e a t m e n t ~ p l a n t . ~}$ 
level, maintaining and distributing AMR microorganisms over long periods of time. Furthermore, the detection of both VIM-1 producing $S$. Infantis and $E$. coli on the same farm was suggestive of the interspecies gene transfer at farm level (Fischer et al., 2017).

Important sources of AMR pathogenic bacteria worldwide are represented by hospitals, which release their sewage drains and wastewater in the environment (Baquero et al., 2008). The spread of CP bacteria from hospitals is a serious menace for the entire ecosystem. Several studies have been performed on aquatic environments, such as hospital sewage, wastewater treatment plants (WWTPs), lakes and rivers and most reports assess that a common way for carbapenemase genes to enter the environment is represented by wastewater. Hospital effluents are normally mixed with urban effluents and treated in WWTPs, to be discharged in the aquatic environment (Verlicchi et al., 2012). In WWTPs, AMR bacteria and their resistant genes can survive (Yang et al., 2016), thus persisting in the environment and spreading back to animals and humans.

WWTPs have been investigated in different countries. In Brazil, the bla $a_{\mathrm{KPC}-2}$ gene was identified in isolates of Aeromonas spp. and Enterobacteriaceae belonging to the genera Klebsiella, Enterobacter, Citrobacter, Serratia, Kluyvera and Roultella present in hospital effluents and WWTPs. The $b l a_{\mathrm{KPC}-2}$ gene of such isolates was successfully transferred in vitro to the recipient strain $E$. coli $\mathrm{J} 53$, showing that it was located either on conjugative or transferable plasmids; this finding supported the hypothesis that the $b l a_{\mathrm{KPC}-2}$ gene could have been transferred to environmental bacteria, such as Aeromonas, Kluyvera and Roultella, from clinical isolates discharged in the hospital sewage (Picão et al., 2013). The acquisition of mobile resistant genes could be promoted by selective pressure exerted by the antimicrobials which are commonly found in hospital sewage (Brown et al., 2006). In Switzerland, in wastewater samples collected before and after the influx of hospital sewage, the increasing of OXA-48 E. coli, OXA-48 C. freundii and KPC-2- or OXA-48 $K$. pneumoniae downstream the hospital wastewater influx was demonstrated (Zurfluh et al., 2017). In Austria, KPC-2 K. pneumoniae, OXA-48 E. coli and OXA$48 \mathrm{~K}$. pneumoniae strains were detected from a WWTP collecting from both domestic and hospital effluents, showing that $\mathrm{CP}$ Enterobacteriaceae could escape from clinical settings to be released into the aquatic environment (Galler et al., 2014). In China, KPC-2 producing bacteria belonging to the genera Klebsiella, Enterococcus, Escherichia, Shigella, Wautersiella, Acinetobacter and Stenotrophomonas were recovered from WWTP effluent samples. Chlorination treatment was not effective, being different genes $\left(b l a_{\mathrm{KPC}-2,}, b_{a_{\mathrm{GES}-1}}\right.$ and $\left.b l a_{\mathrm{IMP}-1}\right)$ detected in large amounts in all sections of the plant. In this study, horizontal transfer of $b l a_{\mathrm{KPC}-2}$ gene was demonstrated in Paenibacillus spp., an environmental microorganism which was never found before to harbor carbapenemase genes (Yang et al., 2016). In Tunisia, bla $a_{\mathrm{KPC}}$, $b l a_{\mathrm{NDM}}$ and $b l a_{\mathrm{OXA}-48 \text { like }}$ genes were detected in high concentrations from hospital wastewater samples, demonstrating the widespread of CP bacteria in hospitals as well as their potential source of environment pollution (Nasri et al., 2017). In Spain, VIM-13-producing $P$. aeruginosa was found in the sewage water of a hospital, together with isolates of VIM-13-producing Brevundimonas diminuta, Rhizobium radiobacter, Pseudomonas monteilii, Ochrobactrum anthropic and Acinetobacter johnsonii. These findings suggested that the environmental microbiota could represent a reservoir of resistance genes, probably acquired by genetic transfer from pathogens like $P$. aeruginosa (Scotta et al., 2011).

Other studies support the hypothesis that "sewage habitats" may represent a niche for AMR microorganisms, enhancing the potential transfer of genetic determinants among different bacterial species (Scotta et al., 2011) and bacterial dissemination to rivers (Novais et al., 2005) and coastal waters (Quinteira and Peixe, 2006). In Portugal, bla $a_{\mathrm{VIM}-2}$-harboring $P$. aeruginosa strains were isolated from a river and a hospital sewage downstream. The $b l a_{\mathrm{VIM}-2}$ gene was located on a class 1 integron (Quinteira and Peixe, 2006). In Tunisia, bla $a_{\mathrm{IMP}-8}, b l a_{\mathrm{IMP}-10}$ and $b l a_{\mathrm{IMP}-13}$ K. pneumoniae isolates were identified from polluted rivers and class 1 integrons were considered the vectors for transmission of bla $a_{\mathrm{IMP}}$ genes among the bacteria (Chouchani et al., 2013). Even seepage water (for example, water pools in streets) might be a source of $\mathrm{CP}$ bacteria, as $b l a_{\mathrm{NDM}}$-harboring $K$. pneumoniae, E. coli, C. freundii, Shigella boydii, Vibrio cholerae, Aeromonas caviae, P. aeruginosa, P. putida, S. maltophilia and other species in India (Walsh et al., 2011). From the Seine River, in Paris (France), bla $a_{\text {OXA-23 }}$-harboring $A$. baumannii was recovered (Girlich et al., 2010a), together with bla $a_{\mathrm{BIC}-1 . h a r b o r i n g} P$. fluorescens (Girlich et al.,2010b). The enzyme BIC-1, a novel class A chromosome-encoded $\beta$-lactamase, hydrolyzes penicillins, carbapenems and cephalosporins, except ceftazidime and monobactams (Girlich et al., 2010b); it shares high identity with SFC-1 from Serratia fonticola (Henriques et al., 2004) and the plasmid-encoded KPC-2 from Klebsiella spp. (Yigit et al., 2003).

At last, the role of natural environment in maintaining and spreading CP microorganisms can be suggested by a study conducted in Switzerland in ready-to-eat vegetables, where OXA-181-producing Klebsiella variicola was identified from a coriander mix sample imported from Thailand/Vietnam (Zurfluh et al., 2015). This finding not only sheds light on the potential role of vegetables in transmitting $\mathrm{CP}$ bacteria to the consumers, but suggests that such a role is very likely attributable to environmental contamination. Nevertheless, contamination of vegetables does not necessary derive from the original harvesting environment, and might originate from the different processing and commercial steps they are subjected as well.

In conclusion, the environment can host CP bacteria both from human and animal sources, maintaining and distributing AMR microorganisms and their genetic determinants to different settings. As recently suggested (Scotta et al., 2011), the environment microbiota can support the genetic transfer among bacteria, especially mediated by class 1 integrons, from pathogenic to environmental microorganisms. The role of the natural environment as reservoir of $\mathrm{CP}$ bacteria is probably more important than what we actually hypothesized. In Europe as well as in other parts of the world, more efforts should be warranted especially in countries where human pathogenic CP microorganisms are endemic.

\section{Wildlife and carbapenemase- producing bacteria}

Actually, the potential role of wildlife in the maintaining and dissemination of resistance genes and AMR bacteria in the natural environment and livestock animals is far to be fully understood. AMR bacteria can colonize wild animals following contact with sewage, human waste or animal manure, with serious issues for public and animal health and ecosystem functions (Pesapane et al., 2013). The intake of water polluted with faeces or human waste seems to be the most important route for wild birds to acquire AMR bacteria of human origin (Guenther et al., 2011). In addition, the intake of polluted water with feaces of livestock animals could have the same importance for wild birds and wild animals to acquire AMR bacteria of farm origin. At present, lonly four studies have detected CP 
bacteria in wild animals (Table 3). The first report originated from Germany, where a strain of bla $a_{\mathrm{NDM}-1}$ Salmonella Corvallis belonging to ST1541 was isolated from black kites (Milvus migrans). The bla $a_{\mathrm{NDM}-1}$ gene was located on the $\sim 180 \mathrm{~kb}$ IncA/C conjugative plasmid pRH-1738 (Fischer et al., 2013b). Since the IncA/C plasmids are among the most common plasmids associated with the $b l a_{\mathrm{NDM}-1}$ gene in humans (Carattoli, 2013) and S. Corvallis was more common in South-East Asia, North Africa and Nigeria rather than in Europe, Fischer and colleagues (2013b) supposed that the isolate might have originated from nonEuropean countries and transferred to Germany through the black kite migratory route. The sequence of the plasmid pRH1738 confirmed this hypothesis (Villa et al., 2015) and the additional presence of the resistant gene for fosfomicin (fos A3), which is common in Asia, strongly supported for the Asiatic origin of the bla $_{\mathrm{NDM}-1, \text { fos } \mathrm{A} 3-\text { har- }}$ boring $S$. Corvallis (Qin et al., 2014).

In France, VIM-1-producing E. coli in yellow-legged gulls (Larus michaellis) has been recently reported (Vittecoq et al., 2017). In the geographical area of the study, yellow-legged gulls live in close contact with humans and all the $\mathrm{CP}$ isolates from gulls were closely related to carbapenemsensitive E. coli of human patients hospitalized in the area. Since the $b l a_{\mathrm{VIM}-1}$ gene is uncommon in France, but can be frequently found in human isolates from Greece, Italy and Spain (Cantón et al., 2012; Mathlouthi et al., 2017) the authors warned over the potential role of wild birds as carriers of carbapenem-resistance bacteria and their encoding genes from endemic countries (Vittecoq et al., 2017).

In south-east Australia, large-scale transmission of IMP-producing bacteria into wild birds was reported. E. coli strains harboring $b l a_{\mathrm{IMP}-4}, b l a_{\mathrm{IMP}-38}$ or $b l a_{\mathrm{IMP}-26}$ genes $K$. pneumoniae harboring $b l a_{\mathrm{IMP}-4}$ or $b l a_{\mathrm{IMP}-}$, ${ }_{26}$ genes, Citrobacter freundii harboring bla $_{\mathrm{IMP}-38}$ gene and Enterobacter aerogenes and Proteus mirabilis harboring bla ${ }_{\mathrm{IMP}-4}$ gene were isolated from silver gulls (Chroicocephalus novaehollandiae). The $b l a_{\mathrm{IMP}-4}$ gene was carried by various conjugative plasmids, mostly IncHI2-N plasmid type, and was associated with a class 1 integron (Dolejska et al., 2016). Interestingly, $b l a_{\mathrm{IMP}-4}$ is the most commonly detected gene among CPE affecting human patients in Australia (Sidjabat et al., 2015; Espedido et al., 2008). PCR mapping revealed the $b l a_{\mathrm{IMP}-4}-\mathrm{qacG}-\mathrm{aacA} 4$-catB3 cassette array in $65 \%$ of $E$. coli isolates and $80 \%$ of non- $E$. coli isolates of gull origin (Dolejska et al., 2016). The same cassette array was found in Enterobacteriaceae from humans in other Australian tows (i.e. Sydney and Melbourne) (Espedido et al., 2008), strongly suggesting the human origin of the IMP-producing E. coli and the other Enterobacteriaceae detected in gulls. The hypothesis was also supported by the feeding habits of the gulls on waste depots, where garbage and sewage were almost exclusively related to human activities and the risk of transmission of bacteria from the human compartment to the wild one was high (Dolejska et al., 2016).

Thus, even if carbapenem-resistance in bacteria from wild animals is rarely reported, the emergence of NDM-1 and IMP carbapenemases in wild birds should not be ignored because of their migratory habits and the consequent ability of long-distance transportation of AMR resistant bacteria and their related genes.

Regarding wild mammals, the first report of OXA-48 producing Enterobacteriaceae originated from Africa. In Algeria, faecal samples from 168 wild boars (Sus scrofa) and 212 barbary macaques (Macaca sylvanus) were collected between 2014 and 2016 and tested for carbapenem-resistant genes. Two $b l a_{\text {OXA-48 }}$ carrying $E$. coli ST635 and one bla $a_{\mathrm{OXA}-48}$ carrying K. pneumoniae ST13 were isolated from wild boars, thus confirming dissemination of $\mathrm{CP}$ bacteria to wild animals (Bachiri et al., 2018) in a country where occurrence of carbapenem-resistant bacteria in humans (Sassi et al., 2014), pets (Yousfi et al., 2015) and livestock animals (Yaici et al., 2016) had been previously reported.

\section{Future studies}

This review has shed light on the main scientific gaps which require future studies, summarized as follows: i) $\mathrm{CP}$ bacteria occurrence in food-producing animals, especially pigs, cattle and poultry, has not been sufficiently investigated in the countries characterized by high prevalence of $\mathrm{CP}$ bacterial infections is humans; ii) the correlation between CP bacteria occurrence and antimicrobial use at farm should be better investigated, with special regard to thirdand fourth-generation cephalosporins use; iii) the observed co-resistance against cephalosporins and carbapenems needs to be investigated by genomic sequencing of the isolates; $i v$ ) comparative genomic studies of CP isolates from humans, animals and the environment should be encouraged to investigate the likely transmission pathways between the different compartments.

\section{Conclusions}

Several factors may contribute to select AMR bacteria in a host, due to their opportunity to become more prevalent as the result of killing the sensitive bacterial population by antimicrobials to which they exhibit reduced susceptibility. As a consequence, the AMR bacteria can become dominant among the previously resident bacterial population (Baquero et al., 2011). Besides this, for many classes of antibiotics, selection of plasmids carrying resistance determinants occurs especially at antimicrobial concentrations far below the MIC value of a susceptible strain. Low antimicrobial concentrations kill only a fraction of the cells, whereas the rest of the bacterial population may evolve to reduced susceptibility or resistance. Accordingly, even the low levels of antibiotics often present in treated animals and humans as well as in polluted natural environments could enhance selection and enrichment of bacteria with transferable resistance genes and thereby contribute to the emergence, maintenance and transmission of AMR bacteria (Guerra et al., 2014; Gullberg et al., 2014).

Among AMR bacteria, CP microorganisms are of particular concern for public health because carbapenems are considered the "last-line defence" drugs against human infections by multidrug resistant Gram-negative bacteria (Zhanel et al., 2007; Nordmann et al., 2011; Patel and Bonomo, 2013). Despite the use of carbapenems in food-producing animals is banned in Europe and other countries (WHO, 2015), detection of CP microorganisms in livestock has been reported in EU as well as non-EU countries. Selection pressure exerted by $\beta$-lactams antimicrobial treatments in farm animals, as well as CP bacteria transmission from human sources, are considered responsible for the occurrence of $\mathrm{CP}$ microorganisms in livestock. Likely, meat and milk might become a source of CP bacteria for the consumers, with the worst scenario to be displayed in countries with high prevalence of $\mathrm{CP}$ bacterial infections in humans.

In this context, the role of hospital sewage and WWTPs in the environmental distribution of human $\mathrm{CP}$ bacteria has been effectively assessed. Furthermore, human activities on natural habitats, as the use of manure to amend soil in agricultural practises, strongly contribute to the diffusion and maintenance of resistance bacteria and their transferable genetic elements in the terrestrial and aquatic environments. In this scenario, wild animals, and especially migratory birds, may amplify both mainte- 
nance and long-distance distribution of $\mathrm{CP}$ microorganisms.

Recently, pollution of the aquatic environment by AMR bacteria, and especially $\mathrm{CP}$ bacteria, has attracted the greatest attention all over the world. Accordingly, even the fishery chain might be responsible for transmission of CP bacteria and their transferable genetic determinants to consumers.

According to the epidemiology of CP bacteria, monitoring studies in food-producing animals, environment and wildlife should be warranted especially in the geographical areas where prevalence of $\mathrm{CP}$ invasive bacteria in humans is high. For instance, in Europe, southern and eastern countries reported the highest prevalence of carbapenem-resistant bacteria in human settings. In decreasing order, CP bacterial infections are mostly reported by Greece, Italy, Romania, Cyprus and Bulgaria for $K$. pneumoniae; by Romania, Latvia, Slovakia, Greece and Hungary for P. aeruginosa; by Croatia, Greece, Lithuania, Romania and Bulgaria for Acinetobacter spp. (ECDC, 2018).

Several studies agree that antibiotic resistance plasmids and other transferable elements are circulating among livestock and wild animals worldwide and across vertebrate species barriers (Chang et al., 2015). Although the overall prevalence of $\mathrm{CP}$ microorganisms in food-producing animals and wildlife appears to be low, CP bacteria transmission from food-producing animals to their derived products could be a threat to consumers, thus promoting mobile carbapenemase gene pools in human enteric flora and supporting transmission of resistant determinants between commensal and pathogenic microorganisms with unknown, but potentially severe, consequences for human health.

\section{References}

Albiger B, Glasner C, Struelens MJ, Grundmann H, Monnet DL; European Survey of Carbapenemase-Producing Enterobacteriaceae (EuSCAPE) working group, 2015. Carbapenemase-producing Enterobacteriaceae in Europe: assessment by national experts from 38 countries. Euro Surveill 20:30062.

Ambler RP, 1980. The structure of beta-lactamases. Philos Trans R Soc Lond B Biol Sci 289:321-31.

Antunes LS, Visca P, Towner KJ, 2014. Acinetobacter baumannii: evolution of a global pathogen. Pathog Dis 71:292301.

Ashiru-Oredope D, Sharland M, Charani E,
McNulty C, Cooke J; ARHAI Antimicrobial Stewardship Group, 2012. Improving the quality of antibiotic prescribing in the NHS by developing a new Antimicrobial Stewardship Programme: Start Smart--Then Focus. J Antimicrob Chemother 67:i51-63.

Aubron C, Laurent Poirel L, Ash R J, Nordmann P, 2005. Carbapenemaseproducing Enterobacteriaceae, U.S. rivers. Emerg Infect Dis 11:260-4.

Bachiri T, Bakour S, Lalaoui R, Belkebla N, Allouache M, Rolain JM, Touati A, 2018. Occurrence of carbapenem-producing Enterobacteriaceae isolates in the wildlife: First report of OXA-48 in wild boars in Algeria. Microb Drug Resist 24:337-45.

Balm MND, La MV, Krishnan P, Jureen R, Lin RT, Teo JW, 2013. Emergence of Klebsiella pneumoniae co-producing NDM-type and OXA-181 carbapenemases. Clin Microbiol Infect 19:E4213.

Baraniak AA, Izdebski R, Fiett J, Herda M, Kania-Pudło M, Młynarczyk G, Marek Gniadkowski M, 2011. Molecular characteristics of KPC-producing Enterobacteriaceae at the early stage of their dissemination in Poland, 20082009. Antimicrob Agents Chemother 55:5493-9.

Baquero F, 2011. The 2010 Garrod Lecture: the dimensions of evolution in antibiotic resistance: ex unibus plurum et ex pluribus unum. J Antimicrob Chemother 66:1659-72.

Baquero F, Martínez J-L, Cantón R, 2008. Antibiotics and antibiotic resistance in water environments. Curr Opin Biotech 19:260-5.

Bathoorn E, JW, Lokate M, AW, Hammerum AM, 2015. Isolation of an NDM-5-producing ST16 Klebsiella pneumoniae from a Dutch patient without travel history abroad, August 2015. Euro Surveill 20:30040.

Blair JM, Richmond GE, Piddock LJ, 2014. Multidrug efflux pumps in Gram-negative bacteria and their role in antibiotic resistance. Future Microbial 9:1165-7.

Brahmi S, Touati A, Cadière A, Djahmi N, Pantel A, Sotto A, Lavigne JP, Dunyach-Remy C, 2016. First description of two sequence type 2 Acinetobacter baumannii isolates carrying OXA-23 carbapenemase in Pagellus acarne Antimicrob Agents Chemother 60:2513-5.

Brown KD, Kulis J, Thomson B, Chapman TH, Mawhinney DB, 2006. Occurrence of antibiotics in hospital, residential, and dairy effluent, municipal wastewa- ter, and the Rio Grande in New Mexico. Sci Total Environ 366:772-83.

Bush K, Fisher JF, 2011. Epidemiological expansion, structural studies, and clinical challenges of new $\beta$-lactamases from Gram-negative bacteria. Annu Rev Microbiol 265:455-78.

Cantón R, Akóva M, Carmeli Y, Giske CG, Glupczynski Y, Gniadkowski M, Livermore DM, Miriagou V, Naas T, Rossolini GM, Samuelsen Ø, Seifert H, Woodford N, Nordmann P; European Network on Carbapenemases, 2012. Rapid evolution and spread of carbapenemases among Enterobacteriaceae in Europe. Clin Microbiol Infect 18:413-31.

Carattoli A, 2013. Plasmids and the spread of resistance. Int $\mathrm{J}$ Med Microbiol 303:298-304.

Carattoli A, 2009. Resistance plasmid families in Enterobacteriaceae. Antimicrob Agents Chemother 53:2227-38.

Carrër A, Poirel L, Yilmaz M, Akan OA, Feriha C, Cuzon G, Matar G, Honderlick P, Nordmann P, 2010. Spread of OXA-48-encoding plasmid in Turkey and beyond. Antimicrob Agents Chemother 54:1369-73.

Chang Q, Wang W, Regev-Yochay G, Lipsitch M, Hanage P, 2015. Antibiotic in agriculture and the risk to human health: how worried should we be? Evol Appl 8:240-4.

Chen D, Gong L, Walsh TR, Lan R, Wang T, Zhang J, Mai W, Ni N, Lu J, Xu J, Li $J, 2016$. Infection by and dissemination of NDM-5-producing Escherichia coli in China. J Antimicrob Chemother 71:563-5.

Chen S, Feng W, Chen J, Liao W, He N, Wang Q, Sun F, Xia P, 2014. Spread of carbapenemase-producing enterobacteria in a southwest hospital in China. Ann Clin Microbiol Antimicrob 13:42.

Cho SY, Huh HJ, Baek JY, Chung NY, Ryu JG, Ki CS, Chung DR, Lee NY, Song JHK, 2015. Klebsiella pneumoniae coproducing NDM-5 and OXA-181 carbapenemases, South Korea. Emerg Infect Dis 21:1088-9.

Chouchani C, Marrakchi R, Henriques I, Correia A, 2013. Occurrence of IMP-8, IMP-10, and IMP-13 metallo- $\beta$-lactamases located on class 1 integrons and other extended-spectrum $\beta$-lactamases in bacterial isolates from Tunisian rivers. Scand J Infect Dis 45:95-103.

Chu YW, Afzal-Shah M, Houang ET, Palepou MI, Lyon DJ, Woodford N, Livermore DM, 2001. IMP-4, a novel metallo-beta-lactamase from nosocomial Acinetobacter spp. collected in Hong Kong between 1994 and 1998. 
Antimicrob Agents Chemother 45:7104.

Connelly S, Subramanian P, Hasan NA, Colwell RR, Kaleko M, 2018. Distinct consequences of amoxicillin and ertapenem exposure in the porcine gut microbiome. Anaerobe 2018 [Epub ahead of print].

Cuzon G, Bonnin RA, Nordmann P, 2013. First identification of novel NDM carbapenemase, NDM-7, in Escherichia coli in France. PLoS One 8:e61322

Cuzon G, Naas T, Nordmann P, 2011. Functional characterization of Tn4401, a Tn3-based transposon involved in blaKPC gene mobilization. Antimicrob Agents Chemother 55:5370-3.

Cuzon G, Naas T, Truong H, Wisell K T, Carmeli Y, Nordmann P, 2010. Worldwide diversity of Klebsiella pneumoniae that produce beta-lactamase blaKPC-2 gene. Emerg Infect Dis 16:1349-56.

de Man TJ, KA, JJ, JK, BM, 2015. Draft genome sequence of a New Delhi metallo-beta-lactamase-5 (NDM-5)-producing multidrug-resistant Escherichia coli isolate. Genome Announc 3:e00017.

Diene SM, Rolain JM, 2014. Carbapenemase genes and genetic platforms in Gram-negative bacilli: Enterobacteriaceae, Pseudomonas and Acinetobacter species. Clin Microbiol Infect 20:831-8.

Dolejska M, Masarikova M, Dobiasova H, Jamborova I, Karpiskova R, Havlicek M, Carlile N, Priddel D, Cizek A, Literak I, 2016. High prevalence of Salmonella and IMP-4-producing Enterobacteriaceae in the silver gull on Five Islands, Australia. J Antimicrob Chemother 71:63-70.

Drawz SM, Bonomo RA, 2010. Three decades of $\beta$ - lactamase inhibitors. Clin Microbiol Rev 23:160-201.

ECDC, 2018. Antimicrobial resistance surveillance in Europe 2017. Annual Report of the European Antimicrobial Resistance Surveillance Network (EARS-Net). Stockholm, Sweden.

EFSA, ECDC, 2018a. The European Union summary report on trends of zoonoses, zoonotic agents and food-borne outbreaks in 2016. EFSA Journal 2018; 16: 5500 .

EFSA, ECDC, 2018b. The European Union summary report on antimicrobial resistance in zoonotic and indicator bacteria from humans, animals and food in 2016. EFSA Journal 16: 5182.

EFSA, ECDC, 2017a. The European Union summary report on trends of zoonoses, zoonotic agents and food-borne out- breaks in 2016. EFSA Journal 2017; 15 : 5077.

EFSA, ECDC, 2017b. The European Union summary report on antimicrobial resistance in zoonotic and indicator bacteria from humans, animals and food in 2015. EFSA Journal; 15: 4694

EFSA, 2013. Scientific Opinion on carbapenem resistance in food animal ecosystems. Available from: www.efsa.europa.eu/en/efsajournal/pub $/ 3501$.

Espedido BA, Partridge SR, Iredell JR, 2008. bla(IMP-4) in different genetic contexts in Enterobacteriaceae isolates from Australia. Antimicrob Agents Chemother 52:2984-7.

EUCAST, 2015. EUCAST guidelines for detection of resistance mechanisms and specific resistances of clinical and /or epidemiological importance. Available from http://www.eucast.org/ fileadmin/src/medi.

Evans BA, Amyes SGB, 2014. OXA $\beta$-lactamases. Clin Microbiol Rev 27:24163.

Falgenhauer L, Ghosh H, Guerra B, Yao Y, Fritzenwanker M, Fischer J, Helmuth R, Imirzalioglu C, Chakraborty T, 2017. Comparative genome analysis of IncHI2 VIM-1 carbapenemase-encoding plasmids of Escherichia coli and Salmonella enterica isolated from a livestock farm in Germany. Vet Microbiol 200:114-7.

Fischer J, San José M, Roschanski N, Schmoger S, Baumann B, Irrgang A, Friese A, Roesler U, Helmuth R, Guerra B, 2017. Spread and persistence of VIM-1 carbapenemase-producing Enterobacteriaceae in three German swine farms in 2011 and 2012. Vet Microbiol 200:118-23

Fischer J, Rodríguez I, Schmoger S, Friese A, Roesler U, Helmuth R, Guerra B, 2013a. Salmonella enterica subsp. enterica producing VIM-1 carbapenemase isolated from livestock farms. J Antimicrob Chemother 68:478-80.

Fischer J, Schmoger S, Jahn S, Helmuth R, Guerra B, 2013b. NDM-1 carbapenemase-producing Salmonella enterica subsp. enterica serovar Corvallis isolated from a wild bird in Germany. J Antimicrob Chemother 68:2954-6.

Fischer J, Rodríguez I, Schmoger S, Friese A, Roesler U, Helmuth R, Guerra B, 2012. Escherichia coli producing VIM1 carbapenemase isolated on a pig farm. J Antimicrob Chemother 67:1793-5.

Galler H, Feierl G, Petternel C, Reinthaler FF, Haas D, Grisold AJ, Luxner J, Zarfel G, 2014. KPC-2 and OXA-48 c a r b a pen e m a s e - h a r boring
Enterobacteriaceae detected in an Austrian wastewater treatment plant. Clin Microbiol Infect 20:132-4.

Girlich D, Poirel L, Nordmann P, 2010a. First isolation of the blaOXA-23 carbapenemase gene from an environmental Acinetobacter baumannii isolate. Antimicrob Agents Chemother 54:5789.

Girlich D, Poirel L, Nordmann P, 2010b. Novel Ambler class A carbapenemhydrolyzing-lactamase from a Pseudomonas fluorescens isolate from the Seine River, Paris, France. Antimicrob Agents Chemother 54:32832.

Gootz TD, Lescoe MK, Dib-Hajj F, Dougherty BA, He W, Della-Latta P, Huard RC, 2009. Genetic organization of transposase region surrounding blaKPC carbapenemase genes on plasmids from Klebsiella strains isolated in a New York city hospital. Antimicrob Agents Chemoter 53:1998-2004.

Goren MG, M Goren M, Carmeli Y, 2010. Transfer of carbapenem-resistant plasmid from Klebsiella pneumoniae ST258 to Escherichia coli in patient. Emerg Infect Dis 16:1014-7.

Govender S, Masunda T, Black J, 2015. VIM-2 carbapenemase-producing Pseudomonas aeruginosa in a patient from Port Elisabeth, South Africa. S Afr Med J 105:328.

Grundmann H, Glasner C, Albiger B, Aanensen DM, Tomlinson CT, Andrasević AT, Cantón R, Carmeli Y, Friedrich AW, Giske CG, Glupczynski Y, Gniadkowski M, Livermore DM, Nordmann P, Poirel L, Rossolini GM, Seifert H, Vatopoulos A, Walsh T, Woodford N, Monnet DL; European Survey of Carbapenemase-Producing Enterobacteriaceae

(EuSCAPE) Working Group, 2017. Occurrence of carbapenemase-producing Klebsiella pneumoniae and Escherichia coli in the European survey of carbapenemaseproducing Enterobacteriaceae (EuSCAPE): a prospective, multinational study. Lancet Infect Dis 17:15363.

Grundmann H, Livermore DM, Giske CG, Canton R, Rossolini GM, Campos J, Vatopoulos A, Gniadkowski M, Toth A, Pfeifer Y, Jarlier V, Carmeli Y; CNSE Working Group, 2010. Carbapenemnon-susceptible Enterobacteriaceae in Europe: conclusions from a meeting of national experts. Euro Surveill 15:19711.

Guenther S, Ewers C, Wieler LH, 2011. Extended-spectrum $\beta$-lactamases producing E. coli in wildlife, yet another 
form of environmental pollution? Front Microbiol 2:246.

Guerra B, Fischer J, Helmuth R, 2014. An emerging public health problem: acquired carbapenemase-producing microorganisms are present in foodproducing animals, their environment, companion animals and wild birds. Vet Microbiol 171:290-7.

Gullberg E, Albrecht LM, KarlssonC, Sandegren L, Andersson DI, 2014. Selection of a multidrug resistance plasmid by sublethal levels of antibiotics and heavy metals. MBio 5:e01918-14.

Hall BG, Barlow M, 2005. Revised Ambler classification of $\beta$-lactamases. $\mathrm{J}$ Antimicrob Chemother 55:1050-1.

Hammerum AM, Littauer P, Hansen F, 2015. Detection of Klebsiella pneumoniae co-producing NDM-7 and OXA181, Escherichia coli producing NDM5 and Acinetobacter baumannii producing OXA-23 in a single patient. Int $\mathrm{J}$ Antimicrob Agents 46:597-8.

Hamza E, Dorghan SM, Hamza DA, 2016. Carbapenemase-producing Klebsiella pneumoniae in broiler poultry farming in Egypt. J Glob Antimicrob Resist 7;810.

Hardiman CA, Hardiman, R. A, Conlan S, P, JP, A J, Sheppard A E, Segre, JA, Frank KM, 2016. Horizontal transfer of carbapenemase-encoding plasmisds and comparison with hospital epidemiology data. Antimicrob Agents Chemother 60:4910-9.

Hauser E, E, Helmuth R, Junker E, Prager R, Schroeter A, Rabsch W, Fruth A, Toboldt A, Malornv B, 2012. Clonal dissemination of Salmonella enterica serovar Infantis in Germany. Chemother 72:90-4.

Henriques I, Moura A, Alves A, Saavedra MJ, Correia A, 2004. Molecular characterization of a carbapenem-hydrolyzing class A B-lactamase, SFC-1, from Serratia fonticola UTAD54. Antimicrob Agents Chemother 48:2321-4

Higgins PG, Bou G, Seifert H, 2013. OXA235, a novel class D beta-lactamase involved in resistance to carbapenems in Acinetobacter baumannii. Antimicrob Agents Chemother 57:2121-6.

Hindermann D, Chase H, Negrete F, Althaus D, Zurfluh K , Tall BD, Stephan R, Nüesch-Inderbinen $M$, 2017. Salmonella enterica serovar Infantis from food and human infections, Switzerland, 2010-2015: poultryrelated multidrug resistant clones and an emerging ESBL producing clonal lineage. Front Microb 8:1322.

Hornsey M, Phee L, Wareham DW, 2011. A novel variant, NDM-5, of the New Delhi metallo- $\beta$-lactamase in a multidrug-resistant Escherichia coli ST648 isolate recovered from a patient in the United Kingdom. Antimicrob Agents Chemother 55:5952-4.

Ho PL, Li Z, Lo WU, Cheung YY, Lin CH, Sham PC, Cheng VC, Ng TK, Que TL, Chow KH, 2012. Identification and characterization of a novel incompatibility group X3 plasmid carrying blaNDM-1 in Enterobacteriaceae isolates with epidemiological links to multiple geographical areas in China. Emerg Microbes Infect 1:e39.

Irrgang A, Grobbel M, SkladnikiewiczZiemer T, Thomas K, Tenhagen BA, 2016. Recurrent detection of VIM-1producing Escherichia coli clone in German pig production. J Antimicrob Chemother 72:944-6.

Janssen J, Kinkade A, Man D, 2015. CARBapenem utilizatiON evaluation in a large community hospital (CARBON): A quality improvement study. Can J Hosp Pharm 68:327-31.

Jaurin B, Grundstrom T, 1981. ampC cephalosporinase of Escherichia coli K12 has a different evolutionary origin from that of $\beta$-lactamases of the penicillinase type. Proc Natl Acad Sci USA 8:4897-901.

Johnson TJ, 2017. Carbapenemase-producing Enterobacteriaceae in swine production in the United States: impact and opportunities. Antimicrob Agents Chemother 61:e02348-16.

Kattan JN, Villegas MV, Quinn JP, 2008. New developments in carbapenems. Clin Microbiol Infect 14: 1102-11.

Kim YK, Song SA, Lee JN, Oh M, Jo KM, Kim HJ, Lee JH, Park J, Jang HJ, Kim HK, Kiem S, 2018. Clinical factors predicting persistent carriage of Klebsiella pneumoniae carbapenemase-producing c a $r$ b a p e n e m-r e s is t a n t Enterobacteriaceae among patients with known carriage. J Hosp Infect 99:40512.

Klotz P, Göttig S, Leidner U, Semmler T, Scheufen S, Ewers C, 2017. Carbapenem-resistance and pathogenicity of bovine Acinetobacter indicus-like isolates. PLoS One 12:e171986.

Krishnaraju M, Kamatchi C, Jha AK, Devasena N, Vennila R, Sumathi G, Vaidyanathan R, 2015. Complete sequencing of an IncX3 plasmid carrying blaNDM-5 allele reveals an early stage in the dissemination of the blaNDM gene. Indian J Med Microbiol 33:30-8.

Lauretti L, Riccio ML, Mazzariol A, Cornaglia G, Amicosante G, Fontana R,
Rossolini GM, 1999. Cloning and characterization of blaVIM, a new integronborne metallo-beta-lactamase gene from a Pseudomonas aeruginosa clinical isolate. Antimicrob Agents Chemother 43:1584-90.

Laxminarayan R, Duse A, Wattal C, Zaidi AK, Wertheim HF, Sumpradit N, Vlieghe E, Hara GL, Gould IM, Goossens H, Greko C, So AD, Bigdeli M, Tomson G, Woodhouse W, Ombaka E, Peralta AQ, Qamar FN, Mir F, Kariuki S, Bhutta ZA, Coates A, Bergstrom R, Wright GD, Brown ED, Cars O, 2013. Antibiotic resistance - the need for global solutions. Lancet Infect Dis 13:1057-98.

Leavitt A, Chmelnitsky I, Ofek I, Carmeli Y, Navon-Venezia S, 2010. Plasmid pkqQIL encoding KPC-3 and TEM-1 confers carbapenem resistance in an extremely drug-resistant epidemic Klebsiella pneumoniae strain. J Antimicrob Chemoth 65:243-8.

Lee K, Lee WG, Uh Y, GY, Cho J, Chong Y, Korean Nationwide Surveillance of Antimicrobial Resistance group, 2003. VIM- and IMP-type metallo-beta-lactamase-producing Pseudomonas spp. and Acinetobacter spp. in Korean hospitals. Emerg Infect Dis 9:868-71.

Liu B-T, Song FJ, Zou M, Zhang QD, Shan H, 2017. High incidence of Escherichia coli strains coharboring mcr-1 and blaNDM from chickens. Antimicrob Agents Chemother 61:e-02347-16.

Liu P, Liu Y, Wang L, La-Gen Wan L, 2016. Draft genome sequence of an NDM-5producing Klebsiella pneumoniae sequence type 14 strain of serotype K2. Genome Announc 4:e01610-1.

Loftie-Eaton W, Rawlings DE, 2012. Diversity, biology and evolution of IncQ-family plasmids. Plasmid 67:1534.

Magiorakos AP, Burns K, Rodríguez Baño J, Borg M, Daikos G, Dumpis U, Lucet JC, Moro ML, Tacconelli E, Simonsen GS, Szilágyi E, Voss A, Weber JT, 2017. Infection prevention and control measures and tools for the prevention of entry of carbapenem-resistant Enterobacteriaceae into healthcare settings: guidance from the European Centre for Disease Prevention and Control. Antimicrob Resist Infect Control 6: 113.

Martinez J, 2009. Environmental pollution by antibiotics and by antibiotic resistance determinants. Environ Pollut 157:2893-902.

Mathers AJ, Peirano G, Pitout JD, 2015. The role of epidemic resistance plasmids and international high-risk clones 
in the spread of multidrug-resistant Enterobacteriaceae. Clin Microbiol Rev 28:565-91.

Mathlouthi N, Al-Bayssari C, Bakour S, Rolain JM, Chouchani C, 2017. Prevalence and emergence of carbapenemases-producing Gram-negative bacteria in Mediterranean basin. Crit Rev Microbiol 43:43-61.

Meletis G, Vavatsi N, Sofianou D, Diza E, 2012. Mechanisms responsible for the emergence of carbapenem-resistance in Pseudomonas aeruginosa. Hippokratia 16:303-7.

Meyer R, 2009. Replication and conjugative mobilization of broad hostrange IncQ plasmids. Plasmid 62:57-70.

Miriagou V,Cornaglia G, Edelstein M, Galani I, Giske CG, Gniadkowski M, Malamou-Lada E, Martinez-Martinez L, Navarro F, Nordmann P, Peixe L, Pournaras S, Rossolini GM, Tsakris A, Vatopoulos A, Cantón R, 2010. Acquired carbapenemases in Gramnegative bacterial pathogens: detection and surveillance issues. Clin Microbiol Infect 16:112-22.

Mollenkopf DF, Stulla JW, Mathys DA, Bowman AS, Feicht SM, Grooters SV, Daniels JB, Wittum TE, 2017. C a r b a pen e m a s e - producing Enterobacteriaceae recovered from the environment of a swine farrow-to-finish operation in the United States. Antimicrob Agents Chemother 61:e01298-16.

Morrison BJ, Rubin JE, 2015. Carbapenemase producing bacteria in the food supply escaping detection. PLoS One 10:e126717.

Muggeo A, Guillard T, Klein F, Reffuveille F, François C, Babosan A, Bajolet O, Bertrand X, de Champs C; CarbaFrEst Group, 2018. Spread of Klebsiella pneumoniae ST395 non-susceptible to carbapenems and resistant to fluoroquinolones in North-Eastern France. J Glob Antimicrob Resist 13:98-103.

Mushtaq S, Irfan S, Sarma JB, Doumith M, Pike R, Pitout J, Livermore DM, Woodford N, 2011. Phylogenetic diversity of Escherichia coli strains producing NDM type carbapenemases. J Antimicrob Chemother 66:2002-5.

Naas T, Dortet L, Iorga BI, 2016. Structural and functional aspects of class A carbapenemases. Curr Drug Targets 17:1006-28.

Naas T, Bentchouala C, Cuzon G, Yaou S, Lezzar A, Smati F, Nordmann P, 2011. Outbreak of Salmonella enterica serotype Infantis producing ArmA 16S RNA methylase and CTX-M-15 extended-spectrum $\beta$-lactamase in a neonatol- ogy ward in Constantine, Algeria. Intern J Antimicrob Agents 38:135-9.

Nakano R, Nakano A, Hikosaka K, Kawakami S, Furukawa T, Suzuki M, K, Ono Y, 2014. First report of metallobeta-lactamase NDM-5-producing Escherichia coli in Japan. Antimicrob Agents Chemother 58:7611-2.

Nasri E, Subirats J, Sànchez-Melsió A, Mansour HB, Borrego CM, Balcázar JL, 2017. Abundance of carbapenemase genes (blaKPC, blaNDM and blaOXA48) in wastewater effluents from Tunisian hospitals. Environ Pollut 229:371-4.

Nordmann P, Naas T, Poirel L, 2011. Global spread of carbapenemase-producing Enterobacteriaceae. Emerg Infect Dis 17;1791-8.

Nordmann P, Cuzon G, Naas T, 2009. The real threat of Klebsiella pneumoniae carbapenemase-producing bacteria. Lancet Infect Dis 9:228-36.

Nordmann P, Mariotte S, Naas T, Labia R, Nicolas MH, 1993. Biochemical properties of a carbapenem-hydrolyzing $\beta$ lactamase from Enterobacter cloacae and cloning of the gene into Escherichia coli. Antimicrob Agents Chemother 37:939-46.

Novais C, Coque TM, Ferreira H, Sousa JC, Peixe L, 2005. Environmental contamination with vancomycin-resistant enterococci from hospital sewage in Portugal. Appl Environ Microbiol 71:3364-8.

Ohsuka S, Arakawa Y, Horii T, Ohta M, 1995. Effect of $\mathrm{pH}$ on activities of novel $\beta$-lactamases and $\beta$-lactamase inhibitors against these $\beta$-lactamases. Antimicrob Agents Chemother 39:1856-8.

Osano E, Arakawa Y, Wacharotayankun R, Ohta M, Horii T, Ito H, Yoshimura F, Kato N, 1994. Molecular characterization of an enterobacterial metallo betalactamase found in a clinical isolate of Serratia marcescens that shows imipenem resistance. Antimicrob Agents Chemother 38:71-8.

Otter JA, Doumith M, Davies F, Mookerjee S, Dyakova E, Gilchrist M, Brannigan ET, Bamford K, Galletly T, Donaldson $\mathrm{H}$, Aanensen DM, Ellington MJ, Hill R, Turton JF, Hopkins KL, Woodford N, Holmes A, 2017. Emergence and clonal spread of colistin resistance due to multiple mutational mechanisms in carbapenemase-producing Klebsiella pneumoniae in London. Sci rep-UK 7:12711.

Papp-Wallace KM, Endimiani A, Taracila MA, Bonomo RA, 2011. Carbapenems: past, present, and future. Antimicrob Agents Chemoter 55:4943-60.
Patel G, Bonomo RA, 2013. "Stormy waters ahead": global emergence of carbapenemases. Front Microbiol 4:48.

Pena I, Picazo JJ, Rodríguez-Avial C, Rodríguez-Avial I, 2014. C a r b a p en e m a s e - p rod u c ing Enterobacteriaceae in a tertiary hospital in Madrid, Spain: high percentage of colistin resistance among VIM-1-producing Klebsiella pneumoniae ST11 isolates. Int $\mathrm{J}$ Antimicrob Agents 43:460-4.

Pesapane R, Ponder M, Alexander KA, 2013. Tracking pathogen transmission at the human-wildlife interface: banded mongoose and Escherichia coli. Ecohealth 10:115-28.

Pfeifer Y, Cullik A, Witte W, 2010. Resistance to cephalosporins and carbapenems in Gram-negative bacterial pathogens. Int $\mathrm{J}$ Med Microbiol 300:371-9.

Picão RC, Cardoso JP, Campana EH, Nicoletti AG, Petrolini FV, Assis DM, Juliano L, Gales AC, 2013. The route of antimicrobial resistance from the hospital effluent to the environment: focus on the occurrence of KPC-producing Aeromonas spp. and Enterobacteriaceae in sewage. Diagn Microbiol Infect Dis 76:80-5.

Pitart C, Solé M, Roca I, Román A, Moreno A, Vila J, Marco F, 2015. Molecular characterization of blaNDM-5 carried on an IncFII plasmid in an Escherichia coli isolate from a nontraveler patient in Spain. Antimicrob Agents Chemother 59:659-62.

Pitout JD, Nordmann P, Poirel L, 2015. Carbapenemase-producing Klebsiella pneumoniae, a key pathogen set for global nosocomial dominance. Antimicrob Agents Chemoter 59:587384.

Poirel L, Berçot B, Millemann Y, Bonnin RA, Pannaux G,Nordmann P, 2012. C a r b a p en e m a s e - producing Acinetobacter spp. in cattle, France. Emerg Infect Dis 18:523-5.

Poirel L, Dortet L, Nordmann P, 2011. Genetic features of blaNDM-1-positive Enterobacteriaceae. Antimicrob Agents Chemother 55:5403-7.

Potron A, Nordmann P, Lafeuille E, Al Rashdi F, Poirel L, 2011. Characterization of OXA-181, a carbapenem-hydrolyzing class D beta-lactamase from Klebsiella pneumoniae. Antimicrob Agents Chemother 55:4896-9.

Pruthvishree BS, Vinodh Kumar OR, Sinha DK, Malik YPS, Dubal ZB, Desingu PA, Shivakumar M, Krishnaswamy N, Singh BR, 2017. Spatial molecular epi- 
demiology of carbapenem-resistant and New Delhi metallo beta-lactamase (blaNDM)-producing Escherichia coli in the piglets of organized farms in India. J Appl Microbiol 122:1537-46.

Pulss S, Semmler T, Prenger-Berninghoff E, Bauerfeind R, Ewers C, 2017. First report of an Escherichia coli strain from swine carrying and OXA-181 carbapenemase and the colisitin determinant MCR-1. Int $J$ Antimicrob Agents 50:232-6.

Qin SS, Fu Y, Zhang Q, Qi H, Wen JG, Xu $\mathrm{H}, \mathrm{Xu} \mathrm{L}$, Zeng L, Tian H, Rong L, Li Y, Shan L, Xu H, Yu Y, Feng X, Liu HM, 2014. High incidence and endemic spread of NDM-1-positive Enterobacteriaceae in Henan Province, China. Antimicrob Agents Chemother 58:4275- 82.

Quinteira S, Peixe L, 2006. Multiniche screening reveals the clinically relevant metallo-beta-lactamase VIM-2 in Pseudomonas aeruginosa far from the hospital setting: an ongoing dispersion process? Appl Environ Microbiol 72:3743-5.

Rahman M, Shukla SK, Prasad KN, Ovejero CM, Pati BK, Tripathi A, Singh A, Srivastava AK, Gonzalez-Zorn B, 2014. Prevalence and molecular charaterization of New Dehli metallo- $\beta$-lactamases NDM-1, NDM-5, NDM-6 and NDM-7 in multidrug resistant Enterobacteriaceae from India. Int $\mathrm{J}$ Antimicrob Agents 44:30-7.

Rasmussen BA, Bush K, Keeney D, Yang Y, Hare R, O'Gara C, Medeiros AA, 1996. Characterization of IMI-1 $\beta$-lactamase, a class A carbapenem-hydrolyzing enzyme from Enterobacter cloacae. Antimicrob Agents Chemother 40:2080-6.

Riccio ML, Pallecchi L, Catania MR, Lagatolla C, Fontana G, 2005. Clonal relatedness and conserved integron structures in epidemiologically unrelated Pseudomonas aeruginosa strains producing the VIM-1 metallo- $\beta$-lactamase from different Italian hospitals. Antimicrob Agents Chemoter 49:10410.

Rimoldi SG, Gentile B, Pagani C, Di Gregorio A, Anselmo A, Palozzi AM, Fortunato A, Pittiglio V, Ridolfo AL, Gismondo MR, Rizzardini G, Lista F, 2017. Whole genome sequencing for the molecular characterization of carbapenem-resistant Klebsiella pneumoniae strains isolated at the Italian ASST Fatebenefratelli Sacco Hospital, 20122014. BMC Infect Dis 17:666.

Rogers C, Basurco B, eds. The use of veterinary drugs and vaccines in
Mediterranean aquaculture. Zaragoza: Centre International de Hautes Etudes Agronomiques Mediterraneennes (CIHEAM) 2009. 223 p. Available from: http://om.ciheam.org/option.php.

Roschanski N, Guenther S, Vu TTT, Fischer J, Semmler T, Huehn S, Alter T, Roesler U, 2017. VIM-1 carbapenemase-producing Escherichia coli isolated from retail seafood, Germany 2016. Euro Surveill 22:17-00032.

Rumbo C, Fernández-Moreira E, Merino M, Mendez JA, Nelson C, Soares NC, Bo G, 2011. Horizontal transfer of the OXA-24 carbapenemase gene via outer membrane vescicles: a new mechanism of dissemination of carbapenem resistant genes in Acinetobacter baumannii. Antimicrob Agents Chemother 55:3084-90.

Sassi A, Dekhil M, Chettibi H, 2014. NDM5 carbapenemase-encoding gene in multidrug-resistant clinical isolates of Escherichia coli from Algeria. Antimicrob Agents Chemother 58:5606-8.

Scotta C, Juan C, Cabot G, Oliver A, Lalucat J, Bennasar A, Albertí S, 2011. Environmental microbiota represents a natural reservoir for dissemination of clinically relevant metallo- $\beta$-lactamases. Antimicrob Agents Chemoter 55:5376-9.

Senda K, Arakawa Y, Ichiyama S, Nakashima K, Ito H, Ohsuka $\mathrm{S}$, Shimokata K, Kato N, Ohta M, 1996. PCR detection of metallo-beta-lactamase gene (blaIMP) in Gram negative rods resistant to broad-spectrum betalactams. J Clin Microbiol 34:2909-13.

Shakibaie MR, Azizi O, Shahcheraghi F, 2017. Insight into stereochemistry of a new IMP allelic variant (IMP-55) metallo- $\beta$-lactamase identified in a clinical strain of Acinetobacter baumannii. Infect Genet Evol 51:118-26.

Sidjabat HE, Townell N, Nimmo GR, George NM, Robson J, Vohra R, Davis L, Heney C, Paterson DL, 2015. Dominance of IMP-4-producing Enterobacter cloacae among carbapenemase-producing Enterobacteriaceae in Australia. Antimicrob Agents Chemother 59:4059-66.

Tato M, Coque TM, Baquero F, Cantón R, 2010. Dispersal of carbapenemase blaVIM-1 gene associated with different Tn402 variants, mercury transposons, and conjugative plasmids in Enterobacteriaceae and Pseudomonas aeruginosa. Antimicrob Agents Chemoter 54:320-7.

Temkin E, Adler A, Lerner A, Carmeli Y, 2014. Carbapenem-resistant
Enterobacteriaceae: biology, epidemiology, and management. Ann NY Acad Sci 1323:22-42.

van Duin D, Doi Y, 2017. The global epidemiology of carbapenemase-producing Enterobacteriaceae. Virulence 8:460-9.

Verlicchi P, Al Aukidy M, Galletti A, Petrovic M, Barceló D, 2012. Hospital effluent: investigation of the concentrations and distribution of pharmaceuticals and environmental risk assessment. Sci Total Environ 430:109-18.

Villa L, Guerra B, Schmoger S, Fischer J, Helmuth R, Zong Z, Garcia-Fernandez A, Carattoli A, 2015. IncA/C plasmid carrying bla(NDM-1), bla(CMY-16), and fosA 3 in a Salmonella enterica serovar Corvallis strain isolated from a migratory wild bird in Germany. Antimicrob Agents Chemoter 59:6597600.

Vittecoq M, Laurens C, Brazier L, Durand P, Elguero E, Arnal A, Thomas F, Aberkane S, Renaud N, Prugnolle F, Solassol J, Jean-Pierre H, Godreuil S, Renaud F, 2017.VIM-1 carbapenemaseproducing Escherichia coli in gulls from southern France. Ecol Evol 7:1224-32.

Wailan AM, Paterson DL, Caffery M, Sowden D, Sidjabat HE, 2015. Draft genome sequence of NDM-5-producing Escherichia coli sequence type 648 and genetic context of blaNDM-5 in Australia. Genome Announc 3:e0019415.

Walsh TR, Weeks J, Livermore DM, Toleman MA, 2011. Dissemination of NDM-1 positive bacteria in the New Delhi environment and its implications for human health: an environmental point prevalence study. Lancet Infect Dis 11:355-62.

Walther-Rasmussen J, Hoiby N, 2006. OXA-type carbapenemases. J Antimicrob Chemother 57: 373-83.

Wang W, Peng Z, Baloch Z, Hu Y, Xu J, Zhang W, Fanning S, Li F, 2017. Genomic characterization of an extensively-drug resistance Salmonella enterica serotype Indiana strain harboring the blaNDM-1 gene isolated on a chicken carcass in China. Microbiol Res 204:48-54.

Wang Y, Wu C, Zhang Q, Qi J, Liu H, Wang Y, He T, Ma L, Lai J, Shen Z, Liu Y, Shen J, 2012. Identification of New Delhi metallo- $\beta$-lactamase 1 in Acinetobacter lwoffii of food animal origin. PLoS One 7:e37152.

Warburg G, Hidalgo-Grass C, Partridge SR, Tolmasky ME, Temper V, Moses AE, Block C, Strahilevitz J, 2012. A carbapenem-resistant Klebsiella pneumo- 
niae epidemic clone in Jerusalem: sequence type 512 carrying a plasmid encoding aac(6_)-Ib. J Antimicrob Chemother 67:898-901.

Webb HE, Bugarel M, den Bakker HC, Nightingale KK, Granier SA, Scott HM, Loneragan GH, 2016. Carbapenem-resistant bacteria recovered from faeces of dairy cattle in the high plains region of the USA. PLoS One 11:e0147363.

WHO, 2017. Critically important antimicrobials list. 5th rev. 2017. Available from http://who.int/foodsafety/publications/antimicrobials-fifth/en/.

WHO, 2015. OIE list of antimicrobials of veterinary importance. Available from https://www.oie.int/doc/ged/D9840.PD F.

Widmann M, Pleiss J, Oelschlaeger P, 2012. Systematic analysis of metallo-beta-lactamases using an automated database. Antimicrob Agents Chemother 56:3481-91.

Winokur PL, Vonstein DL, Hoffman LJ, Uhlenhopp EK, Doern GV, 2001. Evidence for transfer of CMY-2 AmpC beta-lactamase plasmids between Escherichia coli and Salmonella isolates from food animals and humans. Antimicrob Agents Chemother 45:2716-22.

Woodford N, Wareham DW, Guerra B, Teale C, 2014. Carbapenemase-producing Enterobacteriaceae and nonEnterobacteriaceae from animals and the environment: an emerging public health risk of our own making? J Antimicrob Chemother 69:287-91.

Woodford N, Turton JF, Livermore DM, 2011. Multiresistant Gram-negative bacteria: the role of high-risk clones in the dissemination of antibiotic resistance. FEMS Microbiol Rev 35:736-55.

Yaici L, Haenni M, Saras E, Boudehouche W, Touati A, Madec JY, 2016. bla NDM-5-carrying IncX3 plasmid in Escherichia coli ST1284 isolated from raw milk collected in a dairy farm in Algeria. J Antimicrob Chemother 71:2671-2.

Yang YJ, Wu PJ, Livermore DM, 1990. Biochemical characterization of a $\beta$-lactamase that hydrolyzes penems and carbapenems from two Serratia marcescens isolates. Antimicrob Agents Chemother 34:755-8.

Yang F, Mao D, Zhou H, Luo Y, 2016. Prevalence and fate of carbapenemase genes in a wastewater treatment plant in Northern China. PLoS One $11: \mathrm{e} 0156383$.

Yigit H., Queenan AM, Anderson GJ, Domenech-Sanchez A, Biddle JW, Steward CD, Alberti S, Bush K, Tenover FC, 2008. Novel carbapenemhydrolyzing $\beta$-lactamase, KPC- 1 , from a carbapenem-resistant strain of Klebsiella pneumoniae. Antimicrob Agents Chemother 52:809.

Yigit H, Queenan AM, Rasheed JK, Biddle JW, Domenech-Sanchez A, Alberti S, Bush K, Tenover FC, 2003. Carbapenem-resistant strain of Klebsiella oxytoca harboring carbapenem-hydrolyzing beta-lactamase KPC-2 . Antimicrob Agents Chemother 47:3881-9.

Yousfi M, Mairi A, Bakour S, Touati A, Hassissen L, Hadjadj L, Rolain JM, 2015. First report of NDM-5-producing Escherichia coli ST1284 isolated from dog in Bejaia, Algeria. New Microbes New Infect 8:17-8.

Zhanel GG, Wiebe R, Dilay L, Thomson K, Rubinstein E, Hoban DJ, Noreddin AM, Karlowsky JA, 2007. Comparative review of the carbapenems. Drugs 67:1027-52.

Zhang L, Xue W, Meng D, 2016, First report of New Delhi metallo- $\beta$-lactamase 5 (NDM-5)-producing Escherichia coli from blood cultures of three leukemia patients. Int J Infect Dis 42:45-6.

Zhang R, Hu YY, Yang XF, Gu DX, Zhou HW, Hu QF, Zhao K, Yu SF, Chen GX, 2014. Emergence of NDM-producing non-baumannii Acinetobacter spp. isolated from China. Eur J Clin Microbiol 33:853-60.

Zhang WJ, Lu Z, Schwarz S, Zhang RM, Wang XM, Si W, Yu S, Chen L, Liu S, 2013. Complete sequence of the blaNDM-1-carrying plasmid pNDM$\mathrm{AB}$ from Acinetobacter baumannii of food animal origin. J Antimicrob Chemother 68:1681-2.

Zurfluh K, Bagutti C, Brodmann P, Alt M, Schulze J, Fanning S, Stephan R, Nüesch-Inderbinen M, 2017. Wastewater is a reservoir for clinically relevant carbapenemase- and 16s rRNA m e th y l a s e - p r o d u c i n g Enterobacteriaceae. Int $\mathrm{J}$ Antimicrob Agents 50:436-40.

Zurfluh K, Poirel L, Nordmann P, Klumpp J, Stephan R, 2015. First detection of Klebsiella variicola producing OXA181 carbapenemase in fresh vegetable imported from Asia to Switzerland. Antimicrob Resist Infect Control 4:38. 